\title{
KENNISDOCUMENT
}

\section{Indicatiewaarden van aquatische organismen}

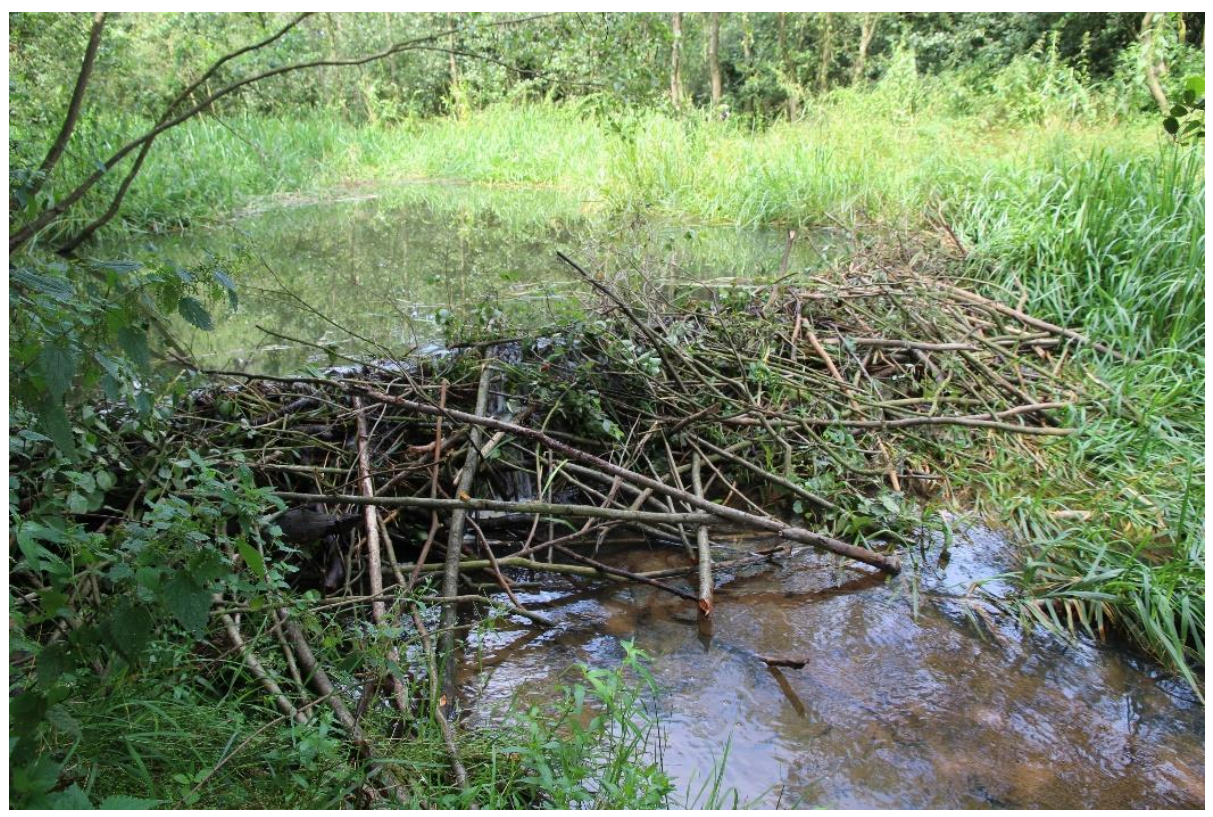

Piet F.M. Verdonschot \& Ralf C.M. Verdonschot 


\section{Referaat}

Biologische gegevens geven inzicht in de oorzaak van effecten van verstoringen op een bepaalde locatie. Hiermee kan een diagnose gesteld worden en biedt ook mogelijkheden om te kunnen voorspellen wat de effecten van herstelmaatregelen zijn die een bepaalde stressor wegnemen of verminderen. Soorten en/of gemeenschappen die onderscheidend en consistent reageren op (groepen van) stressoren worden indicatoren genoemd. Organismegroepen, zoals algen, waterplanten, macrofauna en vis, hebben ieder hun eigen indicatieve waarde, die verschilt op zowel ruimtelijke als temporele schaal. Informatie over hun ecologische en biologische kenmerken met de eigenschappen die daarbij horen, zoals beschikbaar is in databanken, kan nuttig zijn om soort-stressor relaties te duiden. Wanneer van de soortensamenstelling op een locatie een diagnose afgeleid wordt, moet rekening gehouden worden met een groot aantal aspecten die de samenstelling op een locatie bepalen, variërend van het effect van de historie op de samenstelling van de regionale soortenpoule, de biotische en abiotische omstandigheden die werken als 'filters' op de samenstelling van de levensgemeenschap en intrinsieke factoren zoals soorteigenschappen (vooral dispersiecapaciteit), stochasticiteit en dominantie. Dit rapport laat zien dat de aanwezigheid van soorten op een bepaalde locatie niet een één-op-één gevolg is van het abiotische milieu maar dat er veel meer factoren bepalen waarom soorten aan- of afwezig zijn.

\section{Auteurs}

Verdonschot P.F.M. \& Verdonschot R.C.M. (correspondentie: piet.verdonschot@wur.nI)

\section{Opdrachtgever}

Kennisimpuls waterkwaliteit (KIWK)

\section{Projectgroep}

Gebruikerscommissie Kennisimpuls waterkwaliteit Systeemkennis ecologie en waterkwaliteit

\section{Leesgroep}

Bas van der Wal (STOWA), Peter van Puijenbroek (PBL), Gertie Schmidt (Waterschap Vechtstromen), Hermen Klomp (Waterschap Hunze \& Aas)

\section{Wijze van citeren}

Verdonschot P.F.M. \& Verdonschot R.C.M. (2021). Indicatiewaarden van aquatische organismen. Kennisdocument Kennisimpuls waterkwaliteit (KIWK), Zoetwaterecosystemen, Wageningen Environmental Research, Wageningen UR, Wageningen. 46 pp.

\section{Trefwoorden}

Ecologische tolerantie, ecologische preferentie,

\section{Beeldmateriaal}

Piet Verdonschot

DOI: $\underline{\text { https://doi.org/10.18174/556793 }}$

Dit project is uitgevoerd in opdracht van de Kennisimpuls waterkwaliteit (KIWK).

(C) 2021 Zoetwaterecosystemen, Wageningen Environmental Research

- Overname, verveelvoudiging of openbaarmaking van deze uitgave is toegestaan mits met duidelijke bronvermelding.

- Overname, verveelvoudiging of openbaarmaking is niet toegestaan voor commerciële doeleinden en/of geldelijk gewin.

- Overname, verveelvoudiging of openbaarmaking is niet toegestaan voor die gedeelten van deze uitgave waarvan duidelijk is dat de auteursrechten liggen bij derden en/of zijn voorbehouden.

Wageningen Environmental Research aanvaardt geen aansprakelijkheid voor eventuele schade voortvloeiend uit het gebruik van de resultaten van dit onderzoek of de toepassing van de adviezen. 


\section{Inhoud}

Inhoud

$1 \quad$ Inleiding

2 Het nichebegrip; rol van lokale milieu-omstandigheden $\quad 4$

2.1 Soort-factor relatie en ecologische preferentie $\quad 4$

2.2 De ecologische niche 5

$\begin{array}{lll}2.3 & \text { Nicheconstantie en nicheplasticiteit } & 6\end{array}$

2.4 Milieufilters 7

$\begin{array}{ll}2.5 & \text { Extremen in milieu-omstandigheden }\end{array}$

$\begin{array}{lll}2.6 & \text { Piek- en continue verstoring } & 8\end{array}$

$\begin{array}{llr}2.7 & \text { Historische gebeurtenissen } & 8\end{array}$

3 Rol van regionale milieu-omstandigheden $r$

$\begin{array}{ll}3.1 & \text { Omgevingsfilters }\end{array}$

$\begin{array}{ll}3.2 & \text { Connectiviteit en verspreidingscapaciteit }\end{array}$

4 Aanpassingen van en interacties tussen soorten 11

4.1 Biologische aanpassingen $\quad 11$

4.2 Metapopulatie en dispersie $\quad 12$

$\begin{array}{lll}4.3 & \text { Regionale soortenpoule en kolonisatie } & 13\end{array}$

$\begin{array}{lll}4.4 & \text { Stochasticiteit of ecologische variabiliteit } & 14\end{array}$

$\begin{array}{lll}4.5 & \text { Ecologische complexiteit (ecologische netwerken) } & 14\end{array}$

5 Schaal en watertype $r$

$\begin{array}{llr}5.1 & \text { Ruimtelijke en temporele schaal } & 17\end{array}$

$\begin{array}{ll}5.2 \text { Watertypen } & 18\end{array}$

6 Diagnosticeren $r$

$\begin{array}{lll}6.1 & \text { Stressor specifieke indicatoren } & 19\end{array}$

\begin{tabular}{ll}
6.2 & Beschikbare lijsten met indicatiewaarden \\
\hline
\end{tabular}

$\begin{array}{ll}6.3 \text { Gebruikswaarde van indicatoren } & 21\end{array}$

$\begin{array}{lll}6.4 & \text { Keuze van een aquatische indicatorgroep } & 24\end{array}$

$7 \quad$ Hoe verder? $\quad 26$

$\begin{array}{lll}7.1 & \text { Benodigde informatie } & 26\end{array}$

$\begin{array}{lll}7.2 & \text { Informatiebronnen } & 26\end{array}$

8 Literatuur $\quad 29$ 


\section{Inleiding}

Het gebruik van aquatische organismen als indicator van effecten van menselijke activiteiten op oppervlaktewateren dateert van halverwege de 19de eeuw (Davies 1995). Tegenwoordig zijn er wereldwijd talloze biologische beoordelingsprogramma's in gebruik. De resultaten van deze programma's worden bijvoorbeeld gebruikt voor het beoordelen van de ecologische kwaliteit van een locatie, de mate van menselijke beïnvloeding, de mate van doelbereik of een gezond waterleven. Dit is bijvoorbeeld beschreven in de Europese Kaderrichtlijn Water (KRW). Het gebruik van biologische beoordelingsmethoden is inmiddels breed geaccepteerd en het overkoepelend waterkwaliteitsoordeel speelt een belangrijke rol in het beleid.

Daarbij groeit de vraag naar de mogelijkheden om met de biologische gegevens ook inzicht te krijgen in de oorzaak van effecten van verstoringen op een bepaalde locatie. Het gaat hierbij om het stellen van een diagnose (Science Advisory Board 1993, Yoder \& Rankin 1993) en naar de mogelijkheden om te kunnen voorspellen, bijvoorbeeld bij het verminderen van de stress door (herstel)maatregelen. Als soorten en/of gemeenschappen onderscheidend en consistent reageren op individuele (groepen van) stressoren kunnen de oorzaken van een lagere beoordeling locatie-specifiek worden geduid en kunnen relaties tussen stressor(en) en respons(en) voor organismen worden opgesteld. Dergelijke relaties vormen de basis voor diagnoses en voorspellingen.

Lange tijd bestond de opvatting dat voor succesvol herstel van oppervlaktewateren gekwantificeerde kennis van het abiotische milieu van soorten noodzakelijk is. Wanneer de grenswaarden van relevante parameters waarbinnen soorten succesvol overleven bekend zouden zijn, dan zou een waterkwaliteitsprobleem veel beter gediagnosticeerd kunnen worden en zou het effect van maatregelen (het herstel) voorspeld kunnen worden (Figuur 1). Grenswaarden in het milieu zouden de bandbreedte van soorten afbakenen en daarmee al dan niet het voorkomen bepalen. Op het niveau van het ecosysteem wordt een grenswaarde gezien als het punt waarop regulerende terugkoppelingsmechanismen in het ecosysteem overgenomen worden door deregulerende terugkoppelingen (Briske et al. 2006). Op dit punt wordt de maximale veerkracht overschreden en treedt degradatie op, waaronder verlies van soorten.

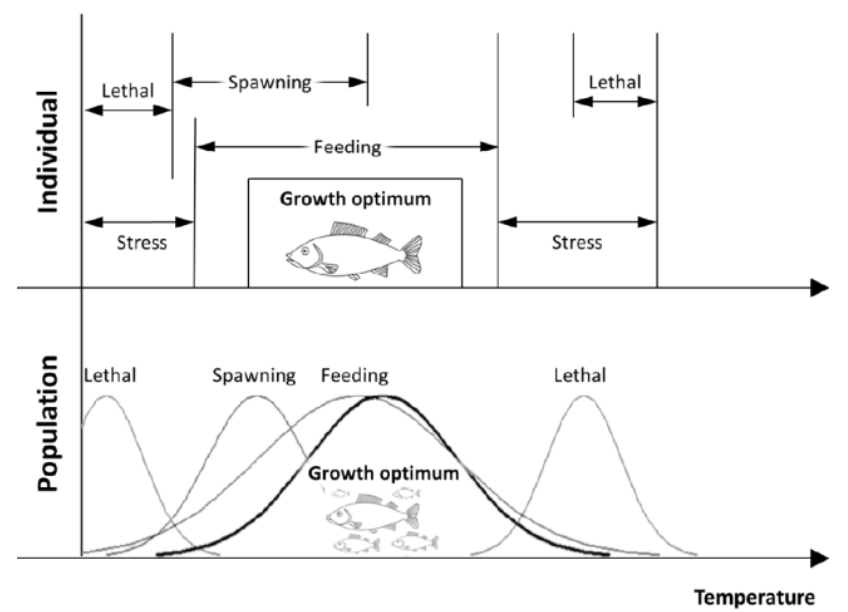

Figuur 1: Voorbeelden van thermische vereisten van een individu en een populatie van een vissoort. De curven in de onderste grafiek vertegenwoordigen de frequentieverdeling van de responsen (Elliott, 1981, Gaudard et al. 2018).

Echter, meer en meer komen we erachter dat niet alle factoren voor alle soorten van belang zijn en dat de factoren onderling verschillen in de mate waarin ze van belang zijn. Daarnaast kan met de huidige kennis van grenswaarden van individuele parameters vaak geen betrouwbare voorspelling worden gedaan. Grenswaarden van relevante factoren kunnen tussen soorten sterk verschillen en soorten reageren niet altijd en overal gelijk op deze factoren. Daarbij geven grenswaarden wel informatie over de kwetsbaarheid van de soort voor betreffende factor, maar deze respons is sterk contextafhankelijk. Bovendien zijn responsies van dezelfde soort verschillend onder verschillende omstandigheden, omdat een milieufactor nooit alleen invloed uitoefent maar altijd deel uitmaakt van een complex van factoren. Individuele factoren beschrijven feitelijk een monofactorieel onderdeel van de potentiële niche van een soort, wat weinig zegt 
over de volledige gerealiseerde of realiseerbare niche van een soort in een specifiek water. Norton et al. (2000) en Poff et al. (2010) lieten zien dat dergelijke relaties beter voor geaggregeerde factoren kunnen worden opgesteld (dan voor individuele factoren. Deze geaggregeerde stressorgroepen zijn bijvoorbeeld de mate van degradatie van de beekdalbegroeiing of de combinatie van verslibbing en voedselverrijking.

Daarnaast speelt tijd een belangrijke rol, vooral wanneer bepaalde milieuomstandigheden een tijdelijk karakter hebben, zoals pieken in de afvoer, dalen in het zuurstofgehalte, droogval of tijdelijke verzilting. Extremen in omstandigheden van dergelijke factoren zijn, wanneer ze tijdens een bepaalde kwetsbare fase van een levenscyclus optreden, meestal de oorzaak van het verdwijnen van soorten. Daarbij reageren niet alleen soorten maar ook organismegroepen sterk verschillend, vaak weer met een bepaalde schaalafhankelijkheid.

Met het abiotische milieu over tijd in beeld zijn we er nog niet. Onderzoek laat steeds duidelijker zien dat ook allerlei biologische werkingsmechanismen van invloed zijn op het voorkomen van soorten. Het gaat hierbij zowel om de intrinsieke aanpassingen van een soort of zelfs een populatie of individu, als om de interacties tussen soorten, zoals parasitisme, predatie en competitie.

Zowel op abiotisch als op biotisch vlak speelt schaal een belangrijke rol. Het bestaan van regionale soortenpoules, de filterwerking van milieu-omstandigheden over verschillende spatio-temporele schalen en de verschillende niveaus warop biologische interacties plaatsvinden maken dat de soortensamenstelling die op een locatie wordt aangetroffen veel meer is dan eenvoudig een soort(sleutel)factorrelatie.

De samenstelling van een lokale gemeenschap in een oppervlaktewater wordt bepaald door de:

Abiotiek (het milieu): de lokale (hoofdstuk 2) en regionale milieu-omstandigheden (hoofdstuk 3) over korte en lange tijd, waaronder bijvoorbeeld het optreden van verstoringen en extremen (afhankelijk van de ecologische preferentie van een soort uitgedrukt over de tijdsperiode om de levenscyclus te voltooien) en de aan verspreiding gerelateerde, vaak regionale, ruimtelijke factoren (connectiviteit).

Biotiek (soortkenmerken): de biologische interacties in het verleden en heden, zoals predatie, competitie, concurrentie en mutualisme, de verspreidings- en vestigingscapaciteit van een soort (bepalend voor de flux van individuen) en de aanwezigheid in de regionale soortenpool (hoofdstuk 4 en 5 ).

In de volgende paragrafen gaan we dieper in op de vraag: 1.) welke factoren en processen een rol spelen bij het interpreteren van de indicatiewaarde van soorten, 2.) op wat hun zeggingskracht kan zijn (hoofdstuk 6) en 3.) hoe (in de toekomst) naar indicatoren kan worden gekeken (hoofdstuk 7). Daarmee geven we een beeld van de huidige kennis van de indicatiewaarde van organismen en de wijze waarop we kunnen diagnosticeren en voorspellen met de informatie afgeleid uit het voorkomen van soorten. 


\section{Het nichebegrip; rol van lokale milieu-omstandigheden}

\subsection{Soort-factor relatie en ecologische preferentie}

Om de niche van een soort te karakteriseren en de range van voorkomen te duiden zijn voor planten en dieren verschillende methoden ontwikkeld. De klassieke benadering was het per milieufactor en soort (monofactoriële soort-factor relatie) berekenen van een optimum en vaak ook tolerantie- of preferentierange. Dit werd gedaan op basis van een (grote) reeks van waarnemingen, waarbij gebruik gemaakt werd van onder andere de volgende parameters:

- gemiddelde (in de Aquatische Macrofyten Diagnose (AQMAD) (van Oorschot et al. 2012);

- de mediaan;

- het gewogen gemiddelde naar abundantie en met een spreiding (tolerantierange, figuur 2) (Verdonschot \& Higler 1992, van Dam 2013, Jaarsma 2016);

- $\quad$ kalibratie van de maximale waarschijnlijkheid op basis van Gauss-logit respons curves (ter Braak \& van Dam 1989);

- $\quad$ schatting gewogen gemiddelde (Bloemendaal \& Roelofs 1988);

- logistische regressie (RISTORI) (ter Braak \& Looman 1986, Durand et al. 1998, Ertsen et al. 2007).

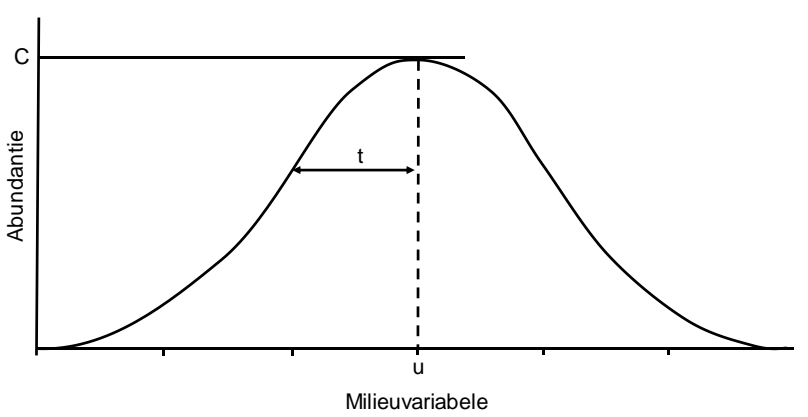

Figuur 2: Gaussische responscurve van de abundantie van een soort en een milieuvariabele ( $u=o p t i m u m$, $t=$ tolerantie, $c=$ maximum) (Verdonschot \& Higler 1992).

Technieken die momenteel veel toegepast worden zijn bijvoorbeeld op regressie gebaseerde univariate Habitat Suitability Curves (HSC), Boosted Regression Trees (BRT), Random Forests (RF) technieken, fuzzylogic-based modellen met behulp van het gewogen gemiddelde (FLWA), maximum membership (FLMM), mean maximum (FLM) en centroid (FLC) defuzzificatie-algoritmen en fuzzy rule-based Bayesian inference (FRB).

Een andere benaderingswijze, die ook bruikbaar is voor biologische kenmerken, is het gebruik van 'fuzzy coding'. Met 'fuzzy coding' wordt milieu- of biologische informatie gestructureerd waarbij positieve scores de affiniteit van een soort beschrijven voor verschillende categorieën (zgn. modaliteiten) van een betreffend kenmerk. In feite wordt de Gaussische responscurve in gewogen klassen verdeeld. In de WEW autecologielijst macrofauna wordt van fuzzy coding gebruik gemaakt (Verberk et al. 2012).

Tenslotte maken de Ecologische BEOordelingssystemen (EBEO) gebruik van de waarde van milieuparameters en indicatiewaarden (0/1-klassen) op grond van aanwezige soorten, de zogenaamde karakteristieken (Franken et al. 2006).

Hoewel enkelvoudige soort-responsrelaties veelvoudig gebruikt worden zijn er kanttekeningen te plaatsen bij de aannames waarop deze relaties zijn gebaseerd. Het gebruik van monofactoriële soort-factor relaties veronderstelt een onafhankelijkheid tussen factoren en een één-op- één respons van een soort op de betreffende factor. Beide aannames zijn vaak onjuist en leiden tot onzekerheid van de resultaten. Een soort is niet afhankelijk van één milieufactor, maar gelijktijdig van verschillende milieufactoren (Figuur 3). Daarom kan een soort niet enkel bij de combinatie van de optimumwaarden van iedere afzonderlijke factor voorkomen, maar is er spreiding en beïnvloeden factoren onderling de aantallen. Zo ontstaan meertoppige verspreidingspatronen van soorten. 


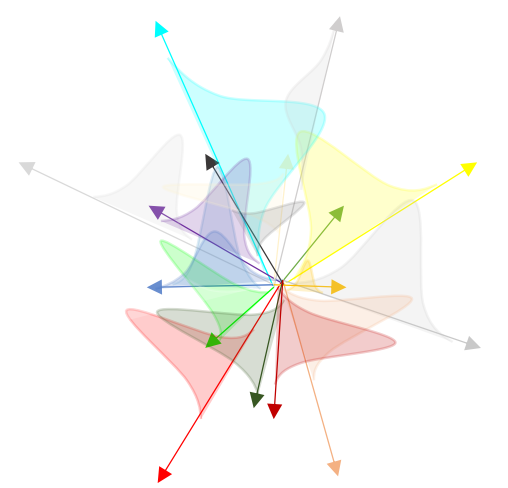

Figuur 3: Multifactoriële (meerdimensionale) ruimte waarbij iedere pijl een milieufactor weergeeft, de Gaussische curve de tolerantie range met optimum en waarbij een soort onder deze combinaties van factoren in delen van de tolerantieruimte zou kunnen voorkomen.

Daarnaast ontstaat bij enkelvoudige soort-factorrelaties in veel gevallen ruis in de berekende uitkomsten doordat:

- De verdeling van monsters over het bereik/het voorkomen van de betreffende soort ongelijk is;

- Een milieufactor kan het negatieve effect van een andere milieufactor opheffen, waardoor de soort juist in hogere aantallen voorkomt dan verwacht. Dit leidt er ook toe dat in verschillende watertypen een soort verschillende optima kan hebben;

- De bemonsterde aantallen van een soort niet alleen afhangt van de waarde van de milieuvariabele, maar ook van de fase in de levenscyclus op het monstermoment;

- Het voorkomen en de aantallen van een soort ook afhankelijk is van biotische interacties (bijvoorbeeld predatie, parasitisme, concurrentie), metapopulatie en dispersiekenmerken.

In plaats van het karakteriseren in termen van individuele milieufactoren van de niche van een enkele soort kan de indicatie ook op basis van een groep van soorten worden bepaald. Het gebruik van groepen van soorten leidt tot een verfijnder beeld van de respons op veranderingen in afzonderlijke milieufactoren of combinaties van milieufactoren, omdat de gevoeligheid tussen soorten voor verandering per factor verschilt (Verdonschot et al. 2003b). Voor het gebruik van groepen van soorten worden soorten die vaak samen voorkomen gegroepeerd in klassen of typen. De classificatie kan op basis van abiotische en biotische kenmerken of een combinatie hiervan worden uitgevoerd. Voorbeelden zijn plantengemeenschappen (Schaminée et al. 1995) en regionale cenotypologieën (Keizer-Vlek \& Verdonschot 2007). Aan groepen van soorten zijn ranges van milieu-omstandigheden gekoppeld, die vervolgens gebruikt kunnen worden om een diagnose te stellen.

Ook groepen van milieufactoren kunnen worden gecombineerd. Een dergelijke opgeschaalde benadering werd gevolgd door Verdonschot et al. (2003a) die aan individuele soorten geclassificeerde indicatiewaarden voor groepen van stressoren (een overall respons) toekenden (soort-multifactor relatie).

Samenvattend blijkt dat een multifactoriële of opgeschaalde benadering kansrijker is om met een combinatie van soorten een uitspraak over de milieu-omstandigheden te doen, omdat zowel abiotische en biotische responses en de interacties ertussen gecombineerd worden meegenomen.

\subsection{De ecologische niche}

In de klassieke ecologische theorieën wordt iedere soort gedefinieerd door een fundamentele en een gerealiseerde niche. Deze twee concepten zijn in de literatuur vaak besproken en zijn onderhevig aan veel definities. Hier gebruiken we de definities die zijn voorgesteld door McGill et al. (2006) en Pearman et al. (2008). De fundamentele niche vertegenwoordigt de subset van de $n$-dimensionale omgevingsruimte van alle mogelijke omstandigheden waarin een soort zichzelf kan handhaven in afwezigheid van concurrentie. Dit kunnen we de 'theoretische niche' noemen. Op een bepaalde locatie vindt er echter interactie tussen soorten en de abiotische en biotische omgeving plaats, waardoor het maximale gebruik van hulpbronnen 
afneemt. Deze waargenomen of gerealiseerde niche van een soort op een bepaalde locatie betreft het deel van de fundamentele niche van betreffende soort, gegeven de biotische en abiotische beperkingen of de context van de locatie en het moment in de tijd (van der Lee 2020a, Figuur 4). Elke verandering in biotische interactie (bijvoorbeeld door competitie) en abiotische omgeving (bijvoorbeeld door stressoren) kan de gerealiseerde niche veranderen. De vergelijking van gerealiseerde en fundamentele niche is dus een veelbelovende benadering om een diagnose op basis van soorten binnen een bepaalde context te stellen.

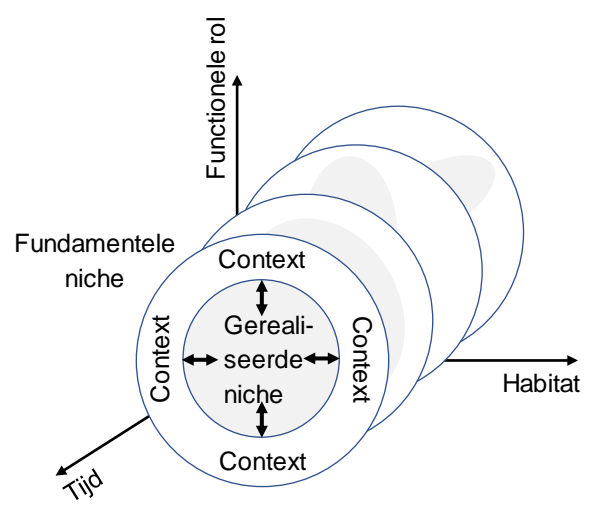

Figuur 4: De ecologische niche van een organisme in termen van waar het leeft (habitat) en wat het doet (functionele rol) in de tijd. De context, dat wil zeggen de omgeving en interacties met andere organismen over meerdere schalen, bepaalt welk deel van de fundamentele niche op een bepaalde tijd en locatie daadwerkelijk gerealiseerd wordt (van der Lee 2020a).

Samenvattend kan worden geconcludeerd dat het onwaarschijnlijk is dat we de multidimensionale niche van alle aquatische soorten in ruimte en tijd over meerdere schalen nauwkeurig zouden kunnen afleiden uit bestaande data of metingen. Toch kan informatie over de ecologische en biologische kenmerken van soorten met hun eigenschappen, zoals beschikbaar is in databanken, nuttig zijn om een (fundamentele) niche te schetsen.

\subsection{Nicheconstantie en nicheplasticiteit}

Een belangrijk aspect bij het voorkomen van soorten is de mate van constantie van de niche in ruimte en tijd. De plasticiteit van de niche van een soort heeft een vergaande ecologische betekenis (Wiens \& Graham 2005, Pearman et al. 2008, Warren et al. 2008). Nicheconstantie betekent dat de soort in het volledige verspreidingsgebied altijd dezelfde niche bewoont en dat ongeschikte omstandigheden het voorkomen beperken (Wiens et al. 2010). Diatomeeën kenmerkend voor zure wateren hebben vaak een sterk nicheconstantie; ze komen op verschillende continenten in dezelfde niche voor. Daartegenover staat nicheplasticiteit, wat betekent dat de niche in ruimte en tijd en dus de indicatorwaarde van dezelfde soort in relatie tot het milieu verschilt tussen gebieden. Zo bewonen sommige macrofyten regiospecifieke niches (Alahuta et al. 2017) en is hun indicatiewaarde ruimtelijk beperkt toepasbaar. Deze regiospecificiteit geldt overigens meer voor drijvende en ondergedoken macrofyten dan voor helofyten. Ook bij sommige macroinvertebraten treedt nicheplasticiteit op, bijvoorbeeld langs een temperatuurgradiënt (ÁngelesGonzález et al. 2020).

Het bestaan van nicheconstantie en -plasticiteit betekent dat databases met soortkenmerken opgebouwd uit gegevens afkomstig van grote biogeografische en klimatologische gebieden, zoals de freshwaterecology.info-database (http://www.freshwaterecology.info; Schmidt-Kloiber \& Hering 2015) met voorzichtigheid moeten worden geïnterpreteerd (Mbaka et al. 2015, Hamilton et al. 2020). Dergelijke databases houden namelijk geen rekening met de grote plasticiteit in aanpassingen die sommige soorten kennen (Ortega-Mayagoitia et al. 2018).

Mogelijk verklaren grootschalige abiotische factoren de geografische verspreiding van een soort en bepalen de fijnschalige ecologische interacties en het gebruik van hulpbronnen de habitatverdeling van betreffende soort (Soberón \& Nakamura 2009). Echter, dit kan per organismegroep sterk verschillen en hierbij speelt de dispersiecapaciteit van de soort een grote rol. De wereldwijde dispersiecapaciteit van veel diatomeeën maakt dat ze een sterk nicheconstantie bezitten. 
Veel vissoorten zijn door hun relatief grote zwemvermogen in staat om, wanneer daar aanleiding voor is, naar gebieden en het habitat te bewegen waar ze optimaal kunnen overleven (Pörtner \& Farrell 2008). Zolang een verstoring niet desastreus is, kan door het zwemgedrag de mate van blootstelling aan stress worden verminderd door te ontsnappen aan de lokale ongunstige omstandigheden (Magnuson et al. 1979). Hierdoor neemt ook de kans af dat de soort lokale aanpassingen ontwikkelt (Buckley et al. 2015, Huey et al. 2003). Met andere woorden, een sterke niche en dispersieplasticiteit (Holt \& Barfield 2004) leidt tot een afname van de mate van specialisatie (Wiens et al. 2010). De mate van nicheplasticiteit wordt nog sterker bij trekkende en predatore vissoorten en gaat vaak gepaard met een grotere lichaamsgrootte, een grotere 'home range' en het gebruik van ruimtelijk meer verspreide hulpbronnen (Holt 1996, Noyola et al. 2013). Dit betekent ook dat volwassen vissen minder indicatief zijn voor lokale habitatomstandigheden, terwijl hun eieren of larven dat wel kunnen zijn.

Kenmerken van nicheconstantie en -plasticiteit en daarmee de invloed van de milieu- en habitatomstandigheden op het voorkomen van een soort hangen dus ook af van het verspreidingsvermogen van de respectievelijke soort (Astorga et al. 2012). Het relatieve belang is daarbij een functie van de grootte van het organisme, levenscycluskenmerken en verspreidingsvermogen.

Samenvattend betekent dat de indicatieve of diagnostische waarde van soorten met een groot nicheconstantie breed toepasbaar is terwijl soorten met nicheplasticiteit veel meer regiospecifiek moeten worden gebruikt.

\subsection{Milieufilters}

Poff et al. (1997) ontwikkelden een raamwerk om de verspreiding en aantallen van soorten binnen gemeenschappen beter te kunnen begrijpen en voorspellen. De kern is dat soorten worden beschreven in termen van hun functionele relaties met hun omgeving (abiotisch en biotisch milieu). Het milieu werkt op verschillende 'landschaps'-schalen (van microhabitats tot stroomgebieden) hierbij als het ware als "filters" die het uiteindelijke voorkomen van een soort bepalen. Grootschalige filters (bijvoorbeeld het klimaat in een regio) zijn randvoorwaarden-scheppend en beperken het soortenpotentieel op lagere schalen. Om als soort op een locatie te kunnen voorkomen, moet deze soort over de juiste functionele kenmerken (soortkenmerken) beschikken om de geschaalde of geneste filters te 'passeren'. Biotische interacties zijn hierbij vooral een belangrijk filter op de lagere schaalniveaus. Het raamwerk legt de nadruk op een biologiegebaseerde benadering voor het begrijpen en voorspellen van de verspreiding en abundantie van soorten en de samenstelling van een lokale gemeenschap, juist doordat expliciet rekening wordt gehouden met beperkingen die het abiotische en biotische milieu op verschillende schalen oplegt.

\subsection{Extremen in milieu-omstandigheden}

Eén van de grote problemen bij de analyse van milieufactoren is het ontbreken van een continu beeld van het verloop van betreffende milieufactor. Een organisme reageert niet op de waarde van een milieufactor op het meetmoment, maar op de waarde daarvan over een kortere of langere tijdsperiode. Een discontinue meting kan uitersten in de range van waarden missen, terwijl juist die uitersten, zoals zuurstofloosheid, grote gevolgen kunnen hebben voor een soort en gemeenschap. Het effect van piekbelastingen of onvoorspelbare, kortstondige verstoringen bepalen vaak het al dan niet voorkomen/verdwijnen van soorten. Voorbeelden zijn extreem hoge piekafvoeren, incidentele droogval of perioden van zuurstofloosheid door hoge temperaturen of incidentele organische en pulsgewijze gifstoffenlozingen. De timing en intensiteit van dergelijke gebeurtenissen zijn bepalend voor het effect op de biologie. Valt een dergelijk extreem in een kwetsbare levensfase van een soort dan zal het effect voor die soort nog veel groter zijn.

Samenvattend blijkt dat soort-factor relaties in belangrijke mate afhankelijk zijn van extremen die optreden in de tijd en de levensfase van het betreffend organisme. 


\subsection{Piek- en continue verstoring}

Verstoringen kunnen worden gekenmerkt door hun intensiteit, frequentie, voorspelbaarheid en duur (Lake 2000, Lévêque 2003). Verstoringen kunnen als puls of piek (snelle en discrete gebeurtenis, zoals een piekafvoer of korte droogval) of als druk optreden (een continu aanhoudende of cumulerende verstoring, zoals een koelwaterlozing) (Figuur 5) (Lake 2000, Stanley et al. 2010). De classificatie van verstoringen in deze categorieën hangt af van de generatietijd van het betreffende organisme. Een verstoring van twee maanden is een continue of cumulerende druk voor een organisme met een generatietijd van enkele weken, maar is een piekverstoring voor een organisme met een generatietijd van een jaar (Underwood 1994). Of de populatiedynamiek daadwerkelijk wordt beïnvloed door een piekverstoring hangt vooral af van het moment waarop de piek optreedt t.o.v. een kritieke periode in de levenscyclus van de blootgestelde soorten (Lancaster \& Downes 2010). Verschillende soorten hebben eigenschappen ontwikkeld om ongunstige omstandigheden te vermijden door bijvoorbeeld tijdens het droge seizoen in rusttoestand te gaan (Hynes 1970), terwijl andere soorten door aanpassingen in generatietijd, migratievermogen en timing en duur van levensfasen, snel herstellen of terug keren na een verstoring. Dergelijke evolutionaire aanpassingen zijn ontwikkeld t.g.v. natuurlijke milieudynamiek en kunnen door betreffende soorten nu worden ingezet bij het overleven van door de mens veroorzaakte dynamiek.

Samenvattend speelt bij de diagnose de wijze waarop piek- of continue stress invloed uitoefent op organismengroepen een belangrijke rol en moet er aandacht zijn voor de juiste tijdschalen i.r.t. de generatietijd van de geselecteerde indicator en de tijdschalen waarop de stressoren werken. Hierbij dient de intensiteit, frequentie, voorspelbaarheid en duur van de verstoring gekoppeld te worden aan de timing van kritieke perioden in de levenscyclus van de blootgestelde soort, mogelijk met behulp van populatiemodellen (van der Lee 2020b).

\subsection{Historische gebeurtenissen}

Gebeurtenissen in het verleden kunnen een aanzienlijke invloed hebben op de samenstelling van de nu aanwezige gemeenschap. Hier spelen drie belangrijke mechanismen een rol. Ten eerste beïnvloedt de aanwezige dominante soort (of soorten) de samenstelling van de andere soorten (Ejrnæs et al. 2006; Hampton et al. 2017). Ten tweede beïnvloeden historische omstandigheden de grootte van de regionale soortenpool, die vervolgens de lokale diversiteit bepaalt (Zobel et al., 2011). Ten derde heeft de respons van lokale diversiteit op milieuveranderingen vaak tijd nodig, de zogenaamde tijdvertraging, wat resulteert in 'legacy'-effecten op de huidige biodiversiteit die de basis vormen van de uitstervingsschuldtheorie (Tilman et al. 1994). Het hiertegenover staande kolonisatiekrediet bij herstel wordt in het kennisdocument 'Tijdvertraging' (Verdonschot \& Verdonschot 2021) uitgebreid besproken.

Het is zeer waarschijnlijk dat de Nederlandse gemeenschappen van macroinvertebraten al eeuwen door menselijke activiteit (zoals grootschalige ontwatering van moerassen, ontbossing, regulering van rivieren, intensivering van de landbouw) zijn beïnvloed en gewijzigd, met een versnelling sinds de tweede helft van de $20^{\text {ste }}$ eeuw waardoor de oorspronkelijk soortenpoule werd teruggebracht tot een poule met veel relatief tolerante taxa. De resterende soortenpoule bestaat daardoor uit een verscheidenheid aan functioneel vergelijkbare taxa die tamelijk willekeurig zijn verdeeld over de wateren in een beperkt gebied als gevolg van stochastische gebeurtenissen (bijvoorbeeld verstoringen). Hierdoor zijn de habitatverschillen op lokale schaal in de huidige situatie de belangrijkste sturende factor (Southwood 1977, Poff \& Ward 1990, Krynak \& Yates 2018). Dit in tegenstelling tot de onder natuurlijke omstandigheden veel grotere soortenrijkdom met functioneel een veel gevarieerdere samentelling die veel explicieter regionale patronen reflecteerden (Bêche \& Statzner 2009, Larsen \& Ormerod 2014, Loreau et al. 2001).

Samenvattend zijn monofactoriële soort-factor relaties ten aanzien van de (lokale) milieufactoren afhankelijk van beschikbare metingen die ook de extremen bevatten die periodiek optreden (m.a.w. behoeven continue meetreeksen), van kennis van de multiple interactie-effecten van combinaties van factoren, van kennis van de effecten van piek- en drukverstoringen op iedere individuele soort en van de historische gebeurtenissen op iedere betrokken locatie. 


\section{Rol van regionale milieu-omstandigheden}

\subsection{Omgevingsfilters}

Een regionale soortenpoule bestaat uit een aantal ruimtelijk gescheiden of lokale populaties van soorten waartussen uitwisseling van individuen kan plaats vinden. De lokale populatieomvang van iedere soort uit de poule wordt bepaald door de lokale milieu-omstandigheden, de biotische interacties en de verspreiding tussen locaties (Leibold \& Miller 2004). De mate van uitwisseling van soorten hangt onder andere af van de regionale milieu-omstandigheden die soorten als het ware 'uitfilteren'. Op de plaatsen met de geschikte habitat- en milieu-omstandigheden komt de soort voor, terwijl in het tussenliggende gebied de omstandigheden niet geschikt zijn voor vestiging. Deze ongeschikte milieu-omstandigheden op regionale schaal zijn voor waterorganismen bijvoorbeeld land, fysische barrières (o.a. stuwen) en fysische weerstand o.a. wind, stroming). Om deze ruimtelijke belemmeringen te overbruggen (o.a. bij het tegen de stroom in zwemmen) moet een organisme energie gebruiken, wat ten koste gaat van andere levensbehoeften.

Wanneer uitwisseling tussen populaties van de soorten die samen een gemeenschap vormen vrijwel afwezig is, dan is de dynamiek in de samenstelling van de lokale gemeenschappen zeer beperkt: m.a.w. er is een grote invloed van ongunstige milieu-omstandigheden (belemmeringen) op een hoog ruimtelijk schaalniveau. Bij een toenemende mate van uitwisseling wordt de rol van de filterwerking door de lokale habitat- en milieu-omstandigheden belangrijker. Bij nog frequentere uitwisseling zullen soorten die talrijk zijn op de bronlocatie en goed dispergeren, ook voor gaan komen op voor betreffende soorten minder geschikte/inferieure habitats (massa-effect). Deze soorten gaan dan deel worden gemeenschappen die minder passend zijn (Mouquet \& Loreau 2003). Wanneer dergelijke massa-effecten regionaal overheersen ontstaat een sterke ruimtelijke metagemeenschapsstructuur (zie ook §4.2) die bij nog verdere uitbreiding tenslotte in feite één gemeenschap vormt.

Samenvattend kan geconcludeerd worden dat omgevingsfilters in belangrijke mate bijdragen aan het wel of niet voorkomen van soorten op een locatie, ongeacht de op die locatie heersende milieuomstandigheden.

\subsection{Connectiviteit en verspreidingscapaciteit}

Uit een studie naar het relatieve belang van aan verspreiding gerelateerde factoren versus lokale milieufactoren voor de lokale gemeenschapssamenstelling van verschillende organismegroepen in meren bleek dat het voorkomen van zich minder gemakkelijk verspreidende grote organismen beter kon worden voorspeld aan de hand van ruimtelijke factoren dan via lokale milieu-omstandigheden, terwijl voor kleine (in de orde van micrometers tot centimeters) organismen, zoals bacteriën en fytoplankton, juist de ruimtelijke component geen rol speelde (Finlay 2002, Beisner et al. 2006, Shurin et al. 2009). Voor vissen was al eerder aangetoond dat lokale milieu-omstandigheden minder van belang zijn (Angermeier \& Schlosser 1989, Olden et al. 2001). Ook zoöplankton bleek niet ruimtelijk te worden beperkt en, afhankelijk van de lokale milieu-omstandigheden, waren bepaalde soorten talrijk.

Daarbij waren verspreiders over land (bijvoorbeeld passieve verspreiding door de wind) meer afhankelijk van de lokale milieu-omstandigheden dan de soorten met een verspreiding via het water. De verspreiders via water waren toleranter voor verschillende milieu-omstandigheden en vestigden zich gemakkelijker (Pace et al. 1992, Walks \& Cyr 2004). Echter, ongeacht de verspreidingsstrategie bleek de productiviteit van meren (totaal fosfor) de belangrijkste voorspeller van de samenstelling van de zoö- en fytoplanktongemeenschap (Dodson et al. 2000, Jeppesen et al. 2000) en bleek koolstof dat voor bacteriën (Eiler et al. 2003). Bij korte verblijftijden wordt de verspreidingsstrategie van kleine organismen wel belangrijker (Lindström et al. 2006). Voor macroinvertebraten bleek dat het vermogen om te vliegen (d.w.z. insecten met een actieve verspreidingsstrategie) tot meer verspreiding leidde t.o.v. passieve verspreiders met vergelijkbare lichaamsgrootte. Macroinvertebraten worden echter in het algemeen sterk in hun verspreiding beperkt als de te overbruggen omgeving ongeschikt is (Astorga et al. 2012). 
Samenvattend kan geconcludeerd worden dat verspreidingscapaciteit van een soort en connectiviteit van het landschap medebepalend zijn voor het wel of niet voorkomen van soorten op een locatie (ongeacht de op die locatie heersende milieu-omstandigheden). 


\section{Aanpassingen van en interacties tussen soorten}

\subsection{Biologische aanpassingen}

De identiteit van een soort of taxon kan gebruikt worden als een surrogaat voor de reeks aanpassingen die ze bezit. De soort heeft tijdens de evolutie aanpassingen ontwikkeld onder invloed de combinatie van omgevingsfactoren. De aanwezigheid van de soort (of meer specifiek een populatie) betekent dat deze soort aanpassingen, kenmerken of "eigenschappen" bezit die nodig zijn om de condities op een locatie het hoofd te bieden (Southwood 1977).

Dergelijke biologische aanpassingen van soorten worden vaak voorgesteld als alternatieve, potentieel gevoeligere indicatoren van stress in vergelijking met de taxonomische duiding (Bonada et al. 2006, Culp et al. 2011, Mouillot et al. 2013, Poff et al. 2006, Verberk et al. 2013). In sommige onderzoeken is zelfs aangetoond dat dergelijke biologische aanpassingen stabieler zijn over grote geografische gebieden en gevoeliger zijn voor veranderingen in het milieu dan de taxonomische (Charvet et al. 2000, Dolédec et al. 1999, Gayraud et al. 2003, Townsend et al. 2008). Andere studies lieten echter nauwelijks verschil zien (Krynak \& Yates 2018) of pleiten voor het gebruik van de taxonomische duiding (Verdonschot \& van der Lee 2020), omdat de soort de drager is van de combinatie van aanpassingen nodig om op die plek te bestaan.

Tegelijk kunnen biologische aanpassingen inzicht bieden in de toestand en het functioneren van systemen die niet noodzakelijkerwijs door taxonomische analyse kunnen worden geduid (Culp et al. 2011, Dolédec et al. 2006, Van den Brink et al. 2011). Enkele voorbeelden zijn de toename van macroinvertebraten met luchtademhaling bij toenemende druk vanuit de landbouw, terwijl de koudwatersoorten afnemen door het wegvallen van grondwaterinvloed en het verwijderen van de beekbegeleidende vegetatie. Dit kan gerelateerd worden aan een verlaging van de zuurstofbeschikbaarheid en verhoging van de watertemperatuur (Allan 2004, Gregory et al. 1991, Poole \& Berman 2001). Verschillende studies lieten ook een verband zien tussen een afname van uni- en semivoltinisme (één generatie of minder per jaar) en reproductiesnelheden bij een dalende stabiliteit (lees toenemende stress) van een systeem (Díaz et al. 2008, Townsend \& Hildrew 1994, Vandewalle et al. 2010). Typisch voor blootstelling aan pesticiden zijn aanpassingen zoals generatietijd, migratievermogen en timing en duur van de verschillende stadia (Liess \& Von der Ohe 2005, Knillmann et al. 2018).

$\mathrm{Er}$ is ook een direct verband tussen biologische aanpassingen en ecologische preferenties (Figuur 5). Een soort heeft verschillende aanpassingen die het mogelijk maken om onder bepaalde combinaties van milieuomstandigheden voor te komen.

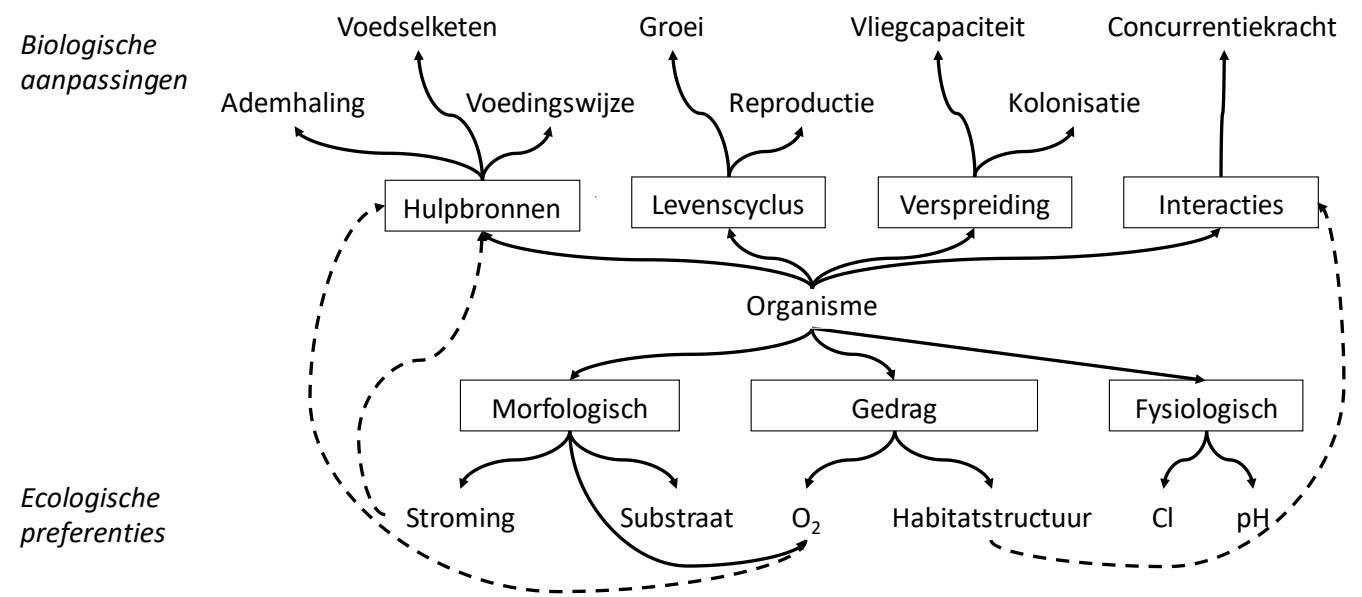

Figuur 5: Voorbeeld van functionele eigenschappen van een soort met biologische eigenschappen en ecologische preferenties (Verdonschot 2014).

Het is van groot belang om de biologische aanpassingen te gebruiken die direct te relateren zijn aan combinaties van milieu-omstandigheden. Poff et al. (2010) gaven een goed voorbeeld van de potentie van 
deze koppeling. Ze onderzochten de verbanden tussen soortspecifieke biologische aanpassingen (hier de kwetsbaarheid van benthische stromend-water-gemeenschappen) en combinaties van milieuomstandigheden over meerdere schalen (hier klimaatverandering). Ze aggregeerden parameters die op beektrajectschaal de chemie, geomorfologie, beekbegeleidende zone en het substraat/habitat beschreven. Op stroomgebiedsschaal onderscheiden ze aggregaties voor geologie, geomorfologie, hydrologie, landgebruik, neerslag en temperatuur. Voor de soortaanpassingen gebruikten ze zeven biologische aanpassingen (Poff et al. 2006): voltinisme, temperatuurtolerantie, voorkomen in drift, gedrag, rheofilie (alle vijf fylogenetisch onafhankelijk) en dispersie (van de vrouwtjes) en droogteresistentie (beide fylogenetisch afhankelijk). De biologische aanpassingen zijn gekozen op hun vermeende relatie met de thermische en hydrologische effecten van klimaatverandering. De analyse toonde aan dat aanpassingen, wanneer geselecteerd op basis van een hypothetische relatie met complexen van milieufactoren over meerdere schalen, significante verbanden oplevert. Dit geeft een aanzet voor diagnostische indicatoren van de toekomst.

Samenvattend wordt duidelijk dat de biologische aanpassingen de basis zijn voor ecologische preferenties voor combinaties van milieu-omstandigheden die tijdens de evolutie zijn voorgekomen en mogelijk nog aanwezig zijn.

\subsection{Metapopulatie en dispersie}

Het vermogen van een organisme om zich te verspreiden is medebepalend voor de lokale samenstelling van de gemeenschap. Wanneer lokale populaties onderling door (beperkte) verspreiding met elkaar zijn verbonden is sprake van een metapopulatie (Leibold et al. 2004). De relatieve rol van de effecten van verspreiding vanuit andere plekken t.o.v. lokale milieu-omstandigheden en hoe deze verhoudingen liggen voor verschillende organismengroepen is belangrijk bij het interpreteren (Cottenie 2005) en het voorspellen van de gemeenschap van een locatie. De verspreiding van een soort hangt af van de lichaamsgrootte (Finlay 2002, De Bie et al. 2012), de levensstrategie (Brown et al. 1996), het type propagules (Peters \& Wassenberg 1983) en het actief of passief kunnen verspreiden. Een propagule is elk materiaal dat functioneert bij het voortplanten van een organisme naar de volgende fase in zijn levenscyclus.

Er bestaat een universeel verband tussen de lichaamsgrootte en een reeks andere biologische aanpassingen van organismen. Zo neemt bij toenemende lichaamsgrootte de grootte, ontwikkelingstijd en groeisnelheid van een populatie af (Brown et al. 2004, Jonsson et al. 2005). Ook speelt lichaamsgrootte een rol in het voedselweb, de diversiteit aan soorten en het ecosysteem functioneren (Brown et al. 200, Woodward et al. 2005). Kleinere organismen vormen grotere populaties (met een kleinere uitstervingskans: Blackburn \& Gaston 1999), vormen meer propagules (Fenchel \& Finlay 2004, Martiny et al. 2006) en door de korte generatietijden en snelle populatiegroei kan de samenstelling snel veranderingen in de lokale milieu-omstandigheden volgen (Korhonen et al. 2010). Na initiële kolonisatie van lege maar geschikte plekken ontwikkelen kleine organismen zich snel. Zo wissen ze ook snel de sporen van uitstervingen in het verleden uit. In vergelijking met grotere organismen zijn kleine organismen dus minder beperkt door aan verspreiding gerelateerde factoren en wordt hun aanwezigheid vooral bepaald door de lokale milieu-omstandigheden die op een bepaald moment aanwezig zijn (Beisner et al. 2006, van der Gucht et al. 2007, Astorga et al. 2012).

Naast de lichaamsgrootte is de dispersie- of verspreidingsstrategie van een soort van belang (Damschen et al. 2008). Verspreidingsstrategieën zijn complex en afhankelijk van soortspecifieke morfologische, fysiologische en gedragsaanpassingen (Bowler \& Benton 2005). Het belangrijkste onderscheid kan worden gemaakt tussen passieve en actieve verspreiding. Bij passieve verspreiding worden propagules verspreid door vectoren, zoals wind, water of dieren (Vanschoenwinkel et al. 2008), en de efficiëntie van passieve verspreiding neemt af met toenemende propagulegrootte (Vagvolgyi 1975, Bruun \& Poschold 2006, Soons et al. 2008). Bij actieve verspreiding is de lichaamsgrootte (Jenkins et al. 2007, Shurin et al. 2009), de verspreidingsstrategie (vliegen, zwemmen) en de kwaliteit en configuratie van verbindingen of connectiviteit (Fahrig \& Merriam 1994) van belang.

Er bestaat dus een sterke relatie tussen lichaamsgrootte (grote organismen zijn veel beperkter in hun verspreiding dan kleine) en de sterkte en omvang van ruimtelijke patronen in metapopulaties. De 
verspreidingsstrategie van een soort verandert dit beeld echter, zo zijn vliegende insecten minder beperkt in hun verspreiding dan passieve verspreiders met dezelfde lichaamsgrootte. Omgekeerd ondervinden actieve verspreiders, die worden beperkt door hydrologische barrières (vissen) of die slechts korte afstanden over land kunnen afleggen (amfibieën), een relatief sterke beperking in de verspreiding op kleine ruimtelijke schaal.

Kolonisatie treedt alleen op als er ook habitat beschikbaar is door veranderingen in het milieu of een aanwezige populatie. Eén van de belangrijkste factoren die bepalen of kolonisatie succesvol zal zijn, is het aantal koloniserende individuen (Griffith et al. 1989, Schoener \& Spiller 1995, Veltman et al. 1996, Berggren 2001). Een groter aantal kolonisten vermindert demografische en stochastische effecten, waardoor de kans op succesvolle vestiging en de ontwikkeling van een levensvatbare populatie sterk vergroot wordt. Andere factoren die het succes van vestiging na kolonisatie beïnvloeden zijn de grootte en kwaliteit van de habitat (Schoener \& Schoener 1983), beschikbaarheid van voedsel en de afwezigheid van predatie (Schoener \& Spiller 1995).

Samenvattend blijkt uit onderzoek naar factoren die de samenstelling van de levensgemeenschap op een locatie bepalen steeds meer dat de verspreidingsstrategie en -route een belangrijke rol spelen. Mogelijk zijn goede verspreiders ook toleranter voor variërende lokale omgevingsomstandigheden, zoals bijvoorbeeld exoten laten zien. De toestand van een aquatisch ecosysteem of soortensamenstelling op locatie reflecteert dus veel meer dan alleen de op dat moment heersende milieu-omstandigheden. Het afleiden van stress uit soortresponsies op milieufactoren kan daarom misleidende informatie geven. Daarom moet de (grote) invloed van verspreidingsmechanismen van soorten en connectiviteit van habitats meegenomen worden in de biologische diagnose.

\subsection{Regionale soortenpoule en kolonisatie}

Elke gemeenschap wordt gevormd uit een subset van de regionale soortenpoule, dat wil zeggen dat de gemeenschap een deel is van alle soorten die regionaal beschikbaar zijn om een bepaalde locatie te koloniseren (Cornell \& Harrison 2014). De fundamentele vraag is dan welke mechanismen bepalend zijn voor de uiteindelijke gemeenschap. De soorten uit de regionale soortenpoule doorlopen verschillende 'filters' (zie ook §2.4), die zowel aspecten van dispersie, milieu-omstandigheden (habitatgeschiktheid) en biotische interacties (zoals competitie) bevatten (Figuur 6) (de Vries 2021). Deze drie onderdelen bepalen tezamen of een soort zich uiteindelijk op de betreffende locatie succesvol vestigt. Dat een habitat geschikt is voor een soort betekent dus nog niet dat de soort de betreffende habitat kan bereiken en er succesvol kan overleven. Er moet ook biologische 'ruimte' zijn om te kunnen vestigen en overleven. Dergelijke 'ruimte' ontstaat vaak pas als er veranderingen in het abiotische milieu (zoals droogte of hoge temperatuur) of in de biotische omstandigheden (zoals de opkomt van een parasiet) optreden, waardoor een aanwezige soort verzwakt, de populatie gereduceerd wordt of geheel verdwijnt. Deze 'ruimte' moet dan ook op het juiste moment ontstaan, precies wanneer de nieuwe soort probeert te koloniseren, zoals het moment van ei-afzetten of zaadontkieming (Švamberková \& Lepš 2020).

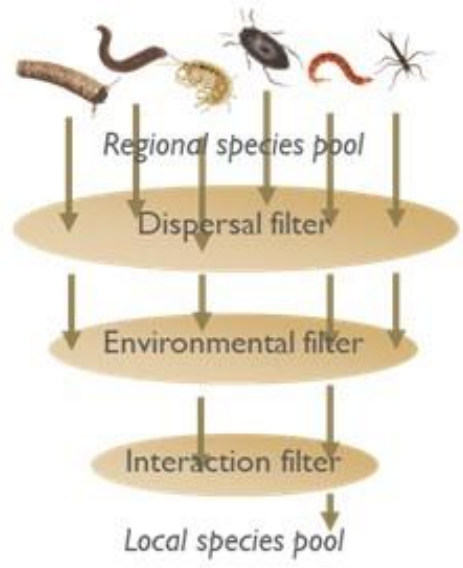


Figuur 4: De soorten uit de regionale soortenpoule doorlopen verschillende 'filters', die bestaan uit zowel aspecten van dispersie, milieu-omstandigheden (habitatgeschiktheid) en biotische interacties (zoals competitie) (de Vries 2021).

\subsection{Stochasticiteit of ecologische variabiliteit}

Interacties tussen soorten (zoals onderlinge concurrentie, predatie, competitie), variabiliteit in populatieopbouw en -samenstelling, levenscycluskenmerken, temporele milieudynamiek en connectiviteit bevatten stochastische (toevals-)processen die bijdragen aan ecologische variatie e dat betekent dat toeval een belangrijke invloed heeft op de lokale soortensamenstelling. Omdat bijvoorbeeld levenskenmerken van individuen in een populatie verschillen ontstaat zogenaamde 'stochastische ecologische variatie' (op toeval gebaseerde verschillen in de soortensamensteling), zoals als gevolg van variatie in individuele vruchtbaarheid, verschillen in individuele groeisnelheid of individueel ervaren (on)gunstigere microhabitatomstandigheden die leiden tot op toeval gebaseerde samenstellingen van gemeenschappen. Hierbij leidt een grotere variatie tussen individuen tot grotere directe en indirecte ecologische veranderingen. Wanneer bijvoorbeeld een populatie op een bepaald trofisch niveau verandert, kan dit gevolgen hebben voor het gehele voedselweb, dus ook de soorten op andere trofische niveaus.

Het belang van ecologische variabiliteit wordt groter naarmate bijvoorbeeld de verschillen in concurrentiekracht tussen soorten toeneemt. Concurrentieverschillen bevoordelen competitief sterke soorten ten koste van een groot aantal zwakkere soorten. Een dergelijke dominantiestructuur wordt vaak veroorzaakt door een hoge reproductie in combinatie met en een lage gevoeligheid voor concurrenten. Voor kleine populaties betekent dit bijvoorbeeld dat concurrentie een grotere invloed heeft op de populatiedynamiek. Omgekeerd vertonen laagabundante soorten vaak een hogere groeisnelheid wat het uitstervingsrisico vermindert, terwijl bij hoog-abundante soorten de groeisnelheid afneemt, wat de kans verkleint dat deze soort een andere soort doet uitsterven (zogenaamde stabiliserende nicheverschillen).

Naarmate gemeenschappen soortenarmer en kleiner worden gaan de relatieve abundanties van de soorten sterker schommelen, waardoor de lokale uitstervingskans groter wordt (lage lokale a-diversiteit [adiversiteit is de diversiteit van een gemeenschap op een bepaalde locatie]) en de ecologische variabiliteit toeneemt. Tegelijk gaan, door de ecologische variabiliteit, meer geïsoleerde, kleinere gemeenschappen een grotere ruimtelijke variatie vertonen (hogere $\beta$-diversiteit [ $\beta$-diversiteit is de mate van verandering in soortensamenstelling van de gemeenschap van verschillende locaties langs een gradiënt of in een gebied of regio]). Naarmate gemeenschappen rijker aan soorten worden, des te meer convergeert de samenstelling (hogere lokale a-diversiteit, lagere $\beta$-diversiteit) en neemt de ecologische variabiliteit af.

Temporele dynamiek in milieu-omstandigheden voegt hier nog extra veranderingen aan toe, bijvoorbeeld wanneer verschillen in groeisnelheden weer leiden tot andere dominantieverhoudingen of tot het naast elkaar blijven bestaan van soorten. Processen op grotere ruimtelijke schalen, zoals metapopulatieprocessen, randeffecten en isolatie, compliceren de ecologische variabiliteit nog verder. Zo leidt fragmentatie tot verlies aan lokale diversiteit en het ontstaan van de zogenoemde uitsterfschuld. Deze term geeft een situatie aan waarin populaties van een soort nog wel aanwezig zijn, maar door hun geringe omvang en gebrek aan uitwisseling met andere populaties niet meer in staat zijn om op de langere termijn duurzaam te blijven voortbestaan.

Samenvattend leidt ecologische variabiliteit (stochasticiteit/toeval) tot een minder voorspelbare soortensamenstelling op een locatie. M.a.w. bij het stellen van een diagnose moet rekening worden gehouden met deze willekeurige variatie, die als onzekerheid moet worden meegenomen.

\subsection{Ecologische complexiteit (ecologische netwerken)}

De soorten die op een locatie aanwezig zijn hebben vaak relaties met (een deel van) de andere aanwezige soorten. De interspecifieke verbindingen, zoals competitie, predatie, mutualisme, parasitisme en concurrentie, worden als een ecologisch netwerk beschouwd. Het type en aantal naast elkaar aanwezige soorten (de soortensamenstelling) op een locatie bepaalt de structuur van dit ecologisch netwerk. Omdat 
een soort steeds direct of indirect met (bijna) alle andere soorten op de locatie verbonden is, zijn ecologische netwerken zeer complex. Montoya et al. (2006) lieten zien dat $80-97 \%$ van de soorten in een voedselweb zich binnen twee of drie schakels van elkaar bevinden. Hoewel de sterkte van de interacties meestal onbekend zijn, blijkt de architectuur van een ecologisch netwerk een belangrijke rol te spelen bij de dynamiek van de gemeenschap, de diversiteit, de veerkracht (tijd om terug te keren naar de 'stabiele' toestand na een verstoring) en de persistentie (het aantal naast elkaar bestaande soorten in de evenwichtstoestand).

De verbindingen in een ecologisch netwerk zijn vaak in elkaar passend; dit wordt 'genest' genoemd. Zo is bijvoorbeeld het dieet van de meest gespecialiseerde soort ook een onderdeel van het dieet van de volgende meer algemene soort en zo is weer zijn dieet een subset van de volgende meer algemene soort. De meest algemene soort kan op die manier de meeste prooisoorten omvatten die in zijn dieet aanwezig zijn. Binnen dit patroon van verbindingen gebaseerd op voedselrelaties bestaan nog andere vormen van genest zijn, met daarbij meer of minder dichte clusters van interacties. Zo heeft in veel gevallen ieder levensstadium van een soort een andere positie in het voedselweb. Er zijn bijvoorbeeld vissen die als larve algen eten, terwijl ze als adult predator zijn en daarmee tijdens hun levenscyclus onderdeel zijn van verschillende voedselwebben (Pimm \& Rice 1987).

De geneste structuur van een ecologisch netwerk, het cascademodel, kan verschillen van enerzijds een volledige directe of indirecte verbondenheid tussen alle soorten (geclusterd verbonden) tot, anderzijds, een duidelijke compartimentering. Waarschijnlijk zijn sterk geclusterde netwerken meer de norm dan ijle netwerken (Woodward \& Hildrew 2002) terwijl gecompartimenteerde netwerken waarschijnlijk meer overeenkomen met habitatgrenzen tussen soortgroepen. Dergelijke grenzen worden overigens mede bepaald door de schaal waarop de levenscyclus van een organisme zich afspeelt. Abundante soorten hebben veel verbindingen met andere soorten omdat ze talrijk zijn, een breder voedselspectrum benutten en meer door predatoren gegeten worden. Grote soorten kunnen zich met meer prooisoorten voeden, hebben meer verbindingen, mede door een groter ruimtelijk areaal, maar zijn vaak ook minder talrijk.

Naast voedselwebben worden ook andere netwerken onderscheiden, zoals mutualistische, commensalistische (i.h.b. ecosysteembouwers) en gastheer-parasiet netwerken. Veel ander type netwerken hebben vaak een kern met een aantal nauw verbonden soorten en een rand waarin de verbindingen ijl zijn. Deze structuur leidt tot minder competitie en een hogere biodiversiteit. Ecosysteembouwers zijn organismen die, direct of indirect, de beschikbaarheid van hulpbronnen of de kwaliteit (fysische en chemische toestand) van het leefgebied voor andere soorten aanpassen (Jones et al. 1994) terwijl 'foundation species', soms in het Nederlands vertaald basissoorten genoemd, juist de habitatstructuur bepalen.

Ecologische netwerken geven de waarschijnlijkheid aan dat verschillende groepen soorten (vertegenwoordigd door knooppunten) samen voorkomen in een landschap, gedefinieerd door de ruimtelijke omvang van de bemonsterde locaties en organismegroep(en) (Arita 2016, Gotelli 2000, Morueta-Holme et al. 2016). Inzicht in het ecologisch netwerk in een oppervlaktewater geeft ook inzicht in de waarde van een diagnose. Er zijn verschillende analysetechnieken beschikbaar. Zo duidt het aantal gerealiseerde verbindingen versus het aantal potentiële de mate van verbondenheid aan en daarmee de veerkracht van het systeem na verstoring (Elmqvist et al. 2003, Tylianakis et al. 2010). De kans dat twee knopen (soorten) zowel direct en indirect verbonden zijn (Girvan en Newman 2002) duidt op de aanwezigheid van redundante paden tussen knooppunten en dus de mate van robuustheid. Naarmate de structuur meer genest is neemt de biodiversiteit toe. In een 'co-occurrence' analyse kan inzicht in een ecologisch netwerk worden verkregen. Wanneer dergelijk netwerken van de streefbeeld- of referentie situatie bekend zijn kunnen de ontbrekende verbanden en soorten inzicht geven in de oorzaken van de verstoring.

Samenvattend biedt inzicht in het ecologisch netwerk de robuustheid en veerkracht van een aquatisch systeem aan en ondersteunt het de ecologische diagnose.

\subsubsection{Netwerkanalyse}

De invloed van soortinteracties en milieu-omstandigheden op een locatie is nog steeds moeilijk te voorspellen (Kissling et al. 2012, Pottier et al. 2013, Thuiller et al. 2013, Wisz et al. 2013, Araújo \& Rozenfeld 2014). Een beter begrip van soortassociaties op verschillende schalen kan leiden tot betere 
voorspellingen van veranderingen in samenstelling die optreden in lokale gemeenschappen wanneer de omgeving verandert (netwerktheorie; Newman 2010). Er is behoefte aan methoden die geschikt zijn om interspecifieke associaties te detecteren op basis van het samen voorkomen van soorten ('co-occurrence'). Soorten zijn geassocieerd of gedissocieerd in groepen door toeval, soortinteracties en hun preferentie of aversie t.o.v. lokale milieu-omstandigheden. Het effect van 'milieufilters' en mogelijkheden en de beperkingen in de verspreiding over meerdere schalen kan worden beoordeeld met behulp van nichemodellen (De Marco et al. 2008, Guisan \& Rahbek 2011, Normand et al. 2011).

Het stapelen van onafhankelijke soort-distributiemodellen (monofactoriële benaderingen), gebaseerd op grootschalig verzamelde ruimtelijke data om gemeenschappen te voorspellen (Guisan \& Rahbek 2011, Calabrese et al. 2014) geeft misleidende voorspellingen op kleine schaal. Een alternatieve benadering is het direct berekenen van soortassociaties en de mechanismen daaruit af te leiden (Bruelheide 2000, Blick \& Burns 2009, Blois et al. 2014). Sinds de jaren zeventig zijn de statistische benaderingen verfijnd om patronen van gelijktijdig voorkomen van meerdere soorten te analyseren (Gotelli \& Ulrich 2010, MoruetaHolme et al. 2016). Hierbij wordt een associatiematrix gevormd waarin de rijen soorten bevatten, de kolommen de locaties en de elementen de waargenomen aanwezigheid/afwezigheid of abundantie van elke soort op elke locatie. De matrix wordt vervolgens vergeleken met een reeks gerandomiseerde matrices om niet-willekeurige patronen van gelijktijdig voorkomen te detecteren (Connor \& Simberloff 1979, Gotelli \& Ulrich 2010). Daarna kunnen in dergelijke modellen de effecten van omgevingsfactoren, interacties tussen soorten of beide worden getest (Gotelli et al. 2010, Ulrich et al. 2012, Araújo et al. 2011, Veech 2013). Belangrijk hierbij is dat indirecte effecten van andere soorten op soortinteracties worden meegenomen, dat 'valse' associaties veroorzaakt door regionale verspreiding worden vermeden, en associaties in een multiple soort-context worden beschreven.

Morueta-Holme et al. (2016) lieten zien dat niet-willekeurige groepen van positief of negatief geassocieerde soorten kunnen worden geïdentificeerd en dat het belang van bepaalde soorten kan worden beoordeeld. Afkhami et al. (2014) toonden voor planten aan dat positieve associaties van soorten veroorzaakt werden door biotische interacties, zoals facilitering tussen zusterbomen en zaailingen, dat stikstoffixatie door bepaalde soorten de bodemvruchtbaarheid voor andere soorten verbeterde, facilitatie door gedeelde bestuivers en zaadverspreiders optrad en relaties van bepaalde soorten met endofytische schimmels aanwezig waren. Positieve associaties kunnen ook een indicatie zijn van gedeelde lokale milieuvereisten, effecten van stabiliserende niche-verschillen (Chesson 2000a,b, Lasky et al. 2014), of een weerspiegeling van historische verspreidingsdynamiek, zoals de uitbreiding vanuit glaciale refugia (Svenning \& Skov 2007). Negatieve associaties van soorten kunnen worden veroorzaakt door biotische interacties zoals competitie of een weerspiegeling zijn van verschillende lokale milieuvereisten. In feite worden fylogenetische (Webb et al. 2002) of functionele (Weiher et al. 2011) eigenschappen gebruikt voor het identificeren van deze mechanismen. Het gebruik van verschillende hulpbronnen kan leiden tot een beeld van positieve associaties van soorten die ieder een complementaire niche innemen (Bolnick et al. 2011, Violle et al. 2011). Door ruimtelijke patronen van associaties te bestuderen zijn bijvoorbeeld ook grootschalige klimaatgradiënten (Brown et al. 1996, Schleuning et al. 2012) of de effecten van hoogteverschillen in berggebieden (Callaway et al. 2002) beschreven. 


\section{Schaal en watertype}

\subsection{Ruimtelijke en temporele schaal}

\subsubsection{Verspreiding en vestiging van soorten}

Organismen functioneren binnen de voor hun levensfasen geschikte abiotische en biotische omstandigheden. Zo zijn algen kleine organismen met een korte levenscyclus en een snelle reproductie, waarmee ze binnen een kort tijdsbestek reageren op veranderingen in zowel natuurlijke en antropogene lokale chemische factoren, vooral pH, geleidendheid en nutriënten (Biggs 1995, Kristiansen 1996, Soininen et al. 2004, Telford et al. 2006, Fierer \& Jackson 2006, Fierer et al. 2007). Algen functioneren daarom binnen een kleine ruimtelijke en temporele schaal.

Waterplanten functioneren daarentegen juist op een grote ruimtelijke en temporele schaal. De grote ruimtelijke schaal is een gevolg van een grote verspreidingscapaciteit en een groot adaptief vermogen. Ruim $60 \%$ van de macrofyten komen op meer dan 1 continent voor (Sculthorpe 1967). Riet (Phragmites australis) is de meest wijdverspreide soort, terwijl ook kroos (Lemna spp.), grof hoornblad (Ceratophyllum demersum), gekroesd fonteinkruid (Potamogeton crispus) en schedefonteinkruid ( $P$. pectinatus) wereldwijd voorkomen. Daarnaast zijn macrofyten erg flexibel en passen ze hun groeivorm, groeisnelheid en timing van bloei en zaadzetting gemakkelijk aan wijzigende milieu-omstandigheden aan (Barrett et al. 1993). Eenmaal gevestigd handhaven sommige soorten macrofyten zich jarenlang, ook al zijn de lokale milieu-omstandigheden negatief veranderd. De wortelstokken van riet kunnen meer dan 6 jaar oud worden (Asaeda et al. 2006) en de klonen kunnen honderden jaren oud worden. Macrofyten hebben sowieso vaak levenscycli met een lengte van één groeiseizoen tot meerdere jaren (Schaumburg et al. 2004).

Macroinvertebraten bestaan uit een grote groep organismen van uiteenlopende ordes, die sterk verschillen in habitateisen en verspreidingscapaciteit. Ze zijn als groep wijd verspreid en komen in bijna alle aquatische systemen voor en bezetten daarbinnen een breed scala aan micro- en mesohabitats, ecotonen en biocoenotische regio's. Ook worden habitats bezet waar andere groepen, zoals macrofyten en vissen, niet voorkomen. Door deze breedte is hun respons op ruimtelijke en temporele schalen zeer variabel. Als gevolg van hun mobiliteit kan een deel van de soorten actief habitats selecteren die voldoen aan hun eisen/voorkeuren, maar tegelijkertijd zijn er ook veel soorten die weinig mobiel zijn waardoor ze indicatief zijn voor lokale milieu-omstandigheden.

Hoe beter de verspreidingscapaciteit (bijvoorbeeld een goed vliegvermogen) van een soort, des kleiner bleek de invloed van de ruimtelijke factoren (Thompson \& Townsend 2006, Astorga et al. 2011, Gothe et al. 2017). Omgekeerd kunnen zwakke verspreiders moeilijk geïsoleerde habitats bereiken. Sterke verspreiders zijn vaak ook geassocieerd met massa-effecten (er treedt dan een hoge mobiliteit op lokale schaal op; De Bie et al. 2012) waarbij de lokale milieu-omstandigheden er minder toe doen (Tonkin et al. 2016). Voor macroinvertebraten met gevleugelde adulten is vooral de oeverzone van groot belang en vormt dit de belangrijkste verspreidingsroute (Petersen et al. 2004; Petersen et al. 2006). Van sommige soorten, bijvoorbeeld sommige libellen en kokerjuffers, is bekend dat de adulten zeer sterke vliegers zijn, die zich over land kunnen verspreiden over verschillende stroomgebieden (Geismar et al. 2015). Passieve verspreiders, zoals weekdieren, volgen de ruimtelijke patronen in watersystemen over afstanden van 1$30 \mathrm{~km}$ (De Bie et al. 2012). In het algemeen is voor passieve verspreiders de relatie tussen lichaamsgrootte en ruimtelijke verspreiding sterk, voor actieve verspreiders is deze relatie veel minder aanwezig (De Bie et al. 2012). Actieve verspreiding kan variabel, context afhankelijk en moeilijk voorspelbaar zijn. Naast de ruimtelijke variatie varieert ook de lengte van de levenscyclus van macroinvertebraten sterk, van dagen tot jaren, waardoor ook langs de tijd-as een grote variatie aan potentiële indicatoren beschikbaar is.

Door deze combinatie en variatie van eigenschappen en het hoge aantal taxa waarvan de ecologische vereisten en functioneel belangrijke eigenschappen bekend zijn is macrofauna bij uitstek geschikt voor diagnose op een regionale schaal (Astorga et al. 2011).

Door hun grote mobiliteit integreren vissen grote ruimtelijke schalen. Door hun vaak relatief grote zwemvermogen zijn veel vissoorten in staat om naar habitats te bewegen waar ze optimaal kunnen overleven, voedsel of schuilplaatsen kunnen vinden, kunnen paaien en kunnen opgroeien. Hierbij kunnen afstanden worden afgelegd variërend van enkele tot honderden of zelfs duizenden kilometers. Daarnaast 
leven vissen relatief lang, ze kunnen verdeeld worden naar leeftijd in drie ongeveer in aantal soorten gelijke groepen van kortlevende ( $<5 \mathrm{jr}$ ), intermediaire (5-15jr) en langlevende soorten ( $>15 \mathrm{jr}$ ) (Noble et al. 2007).

Samenvattend is het voor de diagnose van belang te weten naar welke stressoren wordt gekeken en op welke schaal in ruimte en tijd deze stressoren een rol spelen om de juiste indicatorgroep te kunnen selecteren. Hierbij dient ook rekening te worden gehouden met de fase/stadium binnen de levenscyclus van de soort, omdat er vaak weinig verband is tussen de eigenschappen van zaden en zaailingen t.o.v. volwassen emergente waterplanten, noch tussen de eisen van eitjes van vissen en de volwassen dieren of tussen eerste levensstadia van invertebraten en de adulten. M.a.w. het levensstadium heeft steeds eigen niche-eisen, hetgeen de generieke toepassing van kenmerkenlijsten onzuiver maakt wanneer het stadium of de levensfase niet wordt vermeld. Omgekeerd leidt deze variatie tussen groepen juist tot een hogere kans op meer gedetailleerde diagnosticiteit.

\subsubsection{Schalen en herkenbaarheid van stressoren}

Stressoren spelen op verschillende ruimtelijke en temporele schalen en beïnvloeden daarmee ook de soorten over verschillende schalen. Dit maakt het herleiden van de bron van stress voor diagnose gecompliceerd. Menselijke activiteiten en de daaruit voortkomende stress voor ecosystemen vinden op verschillende schalen plaats en kunnen resulteren in enkelvoudige en multiple stressfactoren. Als gevolg van agrarisch landgebruik kunnen bijvoorbeeld meerdere stressfactoren tegelijkertijd tot uiting komen, zoals een combinatie van eutrofiëring, kanalisatie, waterkwantiteitsbeheer en toxische belasting.

Elk van deze stressoren bestaat zelf ook weer uit individuele stressfactoren, zoals in het geval van eutrofiëring een bepaald fosfaat-, stikstof- en kaliumgehalte. Deze factoren kunnen zowel stuur- en of sleutelfactor zijn. Soorten reageren op deze tweede groep van factoren, waarbij de afzonderlijke factoren een ongelijk belang hebben. Zo is zuurstof een sleutelfactor voor de fauna, terwijl kalium van veel minder belang is. Diagnosticeren met soorten zegt dus veel over de directe sleutelfactor, maar gaande in de hiërarchie naar grotere schaalniveaus neemt de directe zeggingskracht af en moet ook inzicht beschikbaar zijn in de driver-pressure-stressor-impact-response-recovery ketens. Dit zijn de oorzaak-gevolg ketens over verschillende schalen in een stroomgebied.

\subsection{Watertypen}

Omdat veel grootschalige of regionale milieu-omstandigheden een grote invloed kunnen hebben op de verspreiding en vestiging van soorten uit een regionale soortenpoule is het belangrijk deze milieurandvoorwaarden vooraf te kennen. Juist binnen een kader van grootschalige milieu-omstandigheden kan met meer zekerheid een diagnose op basis van de actueel aanwezige soorten worden gesteld, omdat dan tevens rekening wordt gehouden met de actuele soortenpoule. Soorten die ontbreken in de regionale soortenpoule zullen ook niet voor kunnen komen op een locatie binnen die regio. Een dergelijke grootschaligere indeling van milieu-omstandigheden wordt geven in een watertypologie die gebaseerd is op de voor soorten cruciale sleutelfactoren, zoals stromende, droogvallende, diepe, zure of kalkrijke wateren. Onder andere de EBEO-systematiek kende al een indeling in hoofd- en subwatertypen (Franken et al. 2006). Ook Jaarsma (2016) deelde de berekende optima voor macrofyten in naar landschappelijke regio of naar hoofdwatertypen (sloten, kanalen, ondiepe en diepe plassen). Binnen een watertype is voor de diagnose daarnaast de benodigde ruimte met geschikte habitats voor het voltooien van de levenscyclus van een soort van belang (kleinschaligere milieu-omstandigheden).

Samenvattend zijn voor een diagnose gebaseerd op de aanwezige soorten de regionale milieuomstandigheden met de regionale soortenpoule en de lokale milieu-omstandigheden van belang. Het afleiden van diagnostische kenmerken over stressoren binnen een set van regionale sleutelfactoren, samengevat onder de noemer watertype, maakt voor betreffende soort de indicatie- of diagnostische waarde veel nauwkeuriger. 


\section{Diagnosticeren}

\subsection{Stressor specifieke indicatoren}

Verschillende onderzoeken hebben aangetoond dat biologische indices de algemene of totale menselijke verstoring beter aangeven dan het specifieke effect van één of meerdere specifieke stressoren (Hering et al. 2006, Marzin et al. 2012). Echter, een algemene indicatie van de kwaliteit duidt nog geen oorzaken aan. Daarom is meer aandacht nodig voor de beschikbare stressor-specifieke indicatiewaarden van organismen: de ecologische diagnose.

De ecologische diagnose gebruikt organismen om oorzaken van de aangetroffen ecologische toestand van het milieu te duiden en maakt van oudsher gebruik van de taxonomische samenstelling van soort(groep)en als indicatoren van de stressoren of groepen daarvan. Bij de diagnose kan, in navolging van de ecologische beoordeling, de gevonden taxonomische samenstelling van de gemeenschap op locatie vergeleken worden met de regionale watertype-specifiek gedefinieerde referentie- of streefgemeenschap. Verschillen in taxonomische samenstelling geven soorten aan die verdwenen zijn of juist in aantallen zijn toegenomen. De soorten kunnen vervolgens met verschillende stressor-specifieke indices geanalyseerd worden.

De diagnose is bij voorkeur gebaseerd op de indicatie van meerdere soorten, waarbij het verschil tussen de gemeten samenstelling en die van de regionale referentie belangrijk is. Feitelijk wordt gebruik gemaakt van de aard van de biologische verschillen tussen de waargenomen toestand en een referentiebeeld, wat niet een natuurlijk of oorspronkelijk beeld omschrijft, maar een stip (in de toekomst) aan de horizon. Door de diagnose te baseren op monsters genomen op verschillende momenten in de tijd kan een beter beeld van de stressoren en hun werking worden gemaakt, zoals bijvoorbeeld het optreden van stressorpieken. Het verschil tussen huidige en referentietoestand zegt veel over de stress in het water maar nog niets over de oorzaak van de afwijking. Daarvoor is een ecologische systeemanalyse noodzakelijk. Een ecologische systeemanalyse analyseert alle factoren die in samenhang het functioneren van een ecosysteem bepalen, bijvoorbeeld de Stroomgebiedsbrede Ecologische SysteemAnalyse (SESA; Verdonschot \& Verdonschot 2021). Wel wordt met de diagnose duidelijk in welke richting de probleem veroorzakende stressor gezocht moet worden.

Het stellen van een diagnose van de toestand van een aquatisch ecosysteem kan overigens ook worden uitgevoerd door direct gebruik te maken van stressor-specifieke indicatiewaarden van individuele soorten, soortgroepen of ecologische processen zonder gebruik te maken van een regionale en watertype-specifieke referentie. Echter, dit kan leiden tot een grotere ruis in de resultaten.

\subsection{Beschikbare lijsten met indicatiewaarden}

Tot op heden zijn er twee stromingen te onderscheiden in de beschikbare lijsten met indicatiewaarden: ecologische preferentie- of tolerantielijsten en lijsten met biologische soortkenmerken (zgn. traits, adaptaties). Aan beide lijsten kleven nog veel problemen, zoals eerder al herhaaldelijk is benoemd, maar deze lijsten zijn op dit moment de beste beschikbare optie en ze zijn, al dan niet in combinatie, in de basis bruikbaar.

Om een diagnose te kunnen stellen is de beschikbaarheid en vindbaarheid van de in de praktijk bruikbare indicatiewaarden van soorten en groepen van primair belang. Voor de verschillende organismegroepen worden hierna een aantal relevante referenties gegeven. Deze lijst dient als basis en is niet uitputtend. Voor het gebruik dient zorgvuldig gewogen te worden welke lijsten en welke indicatiewaarden daadwerkelijk voor de te analyseren regionale situatie en watertype geschikt en bruikbaar zijn.

\section{Macrofauna}

Europese website: https://www.freshwaterecology.info/

Verdonschot (1990): boek

Verdonschot et al. (1992): https://link.springer.com/content/pdf/10.1007/BF02270810.pdf

van der Hoek \& Verdonschot (1994): 


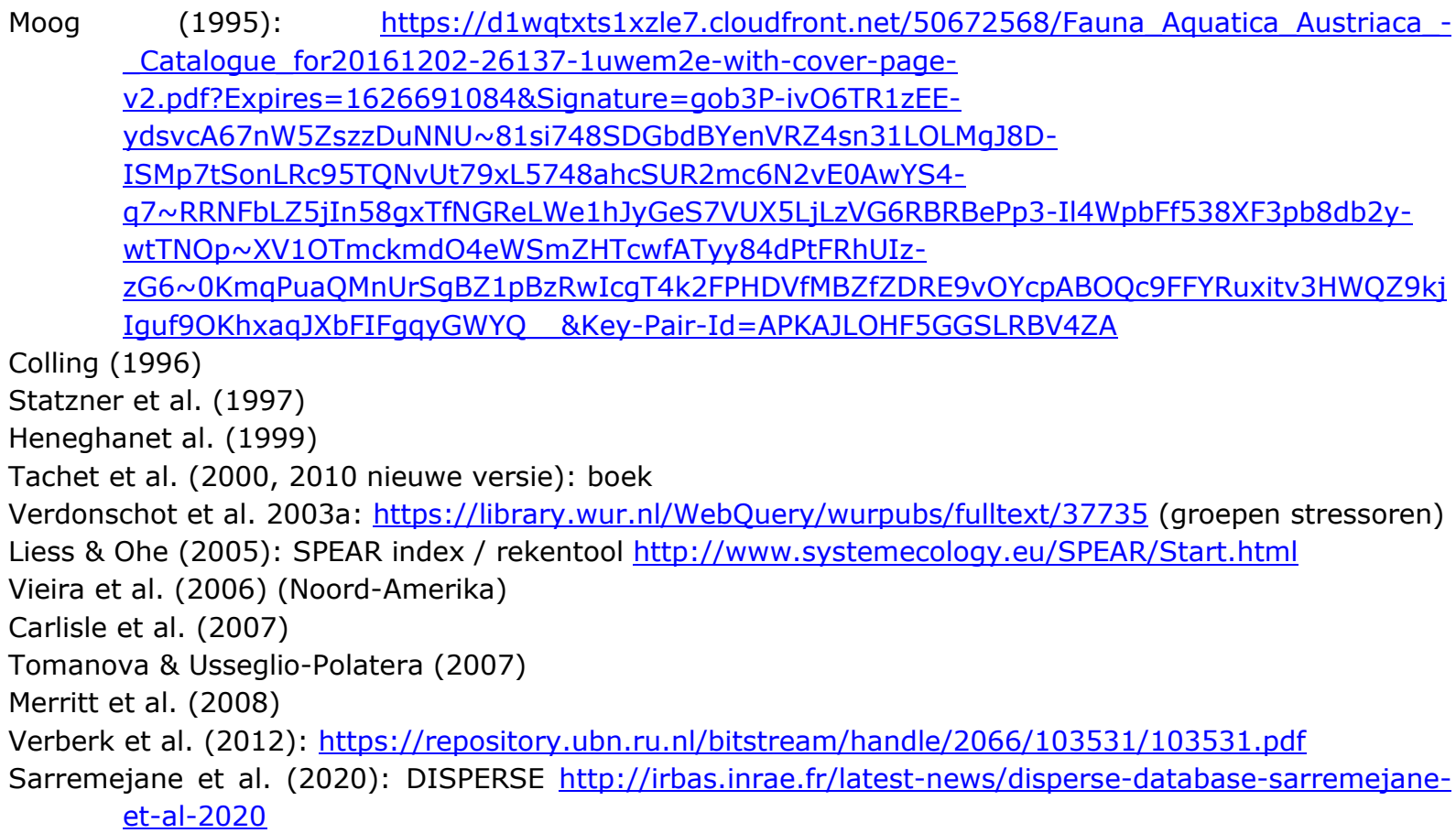

\section{Macrofyten}

Europese website: https://www.freshwaterecology.info/

Website: www.try-db.org

Website: www.leda-traitbase.org

Website: www.icestes.github.io

De Lyon \& Roelofs (1986): https://edepot.wur.nl/386719

Centraal Bureau voor de Statistiek (1991): Botanisch basisregister 1991. Boek

Ellenberg \& Leuschner (2010)

Van Oorschot et al. (2012): AQMAD rekentool https://deltares.shinyapps.io/rAqmad/

Dalla Vecchia et al. (2020)

Barendregt, et. al. (1990)

\section{Vissen}

Website Europees: https://www.freshwaterecology.info/, https://fame.boku.ac.at/downloads.htm Website N. Amerika: http://water.usgs.gov/nawqa/ecology/

Quak J. (1994): https://edepot.wur.nl/355187

\section{Diatomeeën}

Van Dam et al. (1994)

Van Dam (2013): https://library.wur.nl/WebQuery/edepot/278931

Website Europees: https://www.freshwaterecology.info/

Oberdorff et al. (2002)

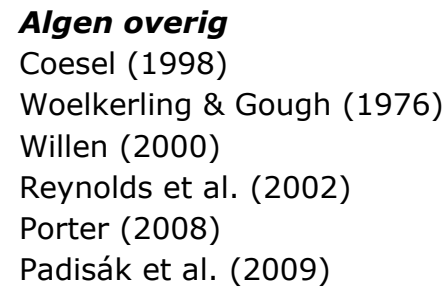

\section{Zoöplankton}

Website: https://www.biodiversity.no/Pages/231126/Small crustaceans in fresh waters

Muñoz-Colmenares et al. (2021)

Lougheed \&Chow-Fraser (2002)

Sládeček (1983) 


\subsection{Gebruikswaarde van indicatoren}

\subsubsection{Algen}

De belangrijkste groepen die in de praktijk onder de noemer algen geschaard worden zijn de blauwalgen of cyanobacteriën (dit zijn echter bacteriën en geen algen), groenalgen, kiezelwieren of diatomeeën en desmidiaceeën (sieralgen). Daarbij wordt vaak onderscheid gemaakt tussen het vrij-zwevend plankton of fytoplankton en de benthische algen, de op de bodem levende algen. Het indelen van hoofdgroepen algen naar hun positionering in een waterlichaam, zoals de veronderstelling dat desmidiaceeën (sieralgen) en diatomeeën vooral benthisch zijn, is onjuist.

Algen hebben een zeer grote ruimtelijke verspreiding; veel soorten komen wereldwijd voor (Bennett et al. 2010, Astorga et al. 2012, de Bie et al. 2012). M.a.w. deze kleine organismen ondervinden niet vaak ruimtelijke beperkingen, waardoor hun aan- of afwezigheid sterk door het lokale milieu bepaald wordt. Tegelijkertijd benutten deze kleine organismen tijdens hun levenscyclus slechts een klein ruimtelijk areaal of habitat. De habitat van fytoplankton is relatief eenvoudig te duiden volgens een hiërarchie van factoren: permanent of tijdelijk water, chloridegehalte en andere ionen, diepte, afstand tot de oever, menging, instraling, zuurstofgehalte, zuurgraad en nutriënten (Reynolds 2012). Het fytoplankton is weinig indicatief voor andere dan directe chemische factoren in de waterkolom. Daarnaast bepalen een aantal factoren de gemeenschapssamenstelling, zoals intrinsieke kenmerken ('drijf'vermogen om in suspensie te blijven of te 'zinken', omgang met lichtcondities, opname-efficiëntie), biologische interacties (begrazing, parasieten, populatiedichtheidsstratificatie) en abiotische interacties (extreme milieu-omstandigheden, zoals ultraoligotrofe condities). Juist de intrinsieke kenmerken en de biologische interacties maken dat de samenstelling van de algengemeenschap moeilijk voorspelbaar is, noch dat deze altijd direct gerelateerd is aan specifieke milieu-omstandigheden. Toch hebben Reynolds et al. (2002) en Padisák et al. (2009)een functionele typologie opgesteld om patronen in algensamenstellingen in diverse aquatische ecosystemen te beschrijven.

Door de korte levenscyclus en snelle reproductie van algen worden ze vaak gebruikt als snel- en vroegsignaleringssysteem ('quick and early warning'). Door de snelle respons op veranderingen in omstandigheden zijn hoogfrequente bemonsteringen (momentopnames) nodig om een betrouwbare diagnose van de toestand te krijgen (Beisner et al. 2006). Waarnemingen zijn sterk afhankelijk van de juiste timing en frequentie van bemonstering, die bijvoorbeeld ook afhangt van de locatie van het water, de weersomstandigheden, de morfologie van het systeem en de diepte van monstername. Maar ook biologische processen, zoals het effect van zoöplankton-begrazing, zijn van grote invloed op de samenstelling (Lepistö 1999, Willén 2000). Daarnaast kunnen massa-effecten (de verspreiding van soorten talrijk op een locatie naar minder geschikte naburige locaties), juist bij kleine organismen, de rol van de werkelijke milieu-omstandigheden in het bepalen van de soortensamenstelling vertroebelen.

Samenvattend is bij het gebruik van algen altijd een hoogfrequente bemonstering in ruimte en tijd noodzakelijk. Andere problemen met het gebruik van algen komen voort uit de taxonomische kwaliteit, die sterk afhankelijk is van de ervaring en vaardigheid van de onderzoeker, de determinatiewerken en de apparatuur en de intercalibratie die hierbij noodzakelijk is (Niemi et al. 1985).

\subsubsection{Macrofyten}

Macrofyten worden meestal onderverdeeld naar de belangrijkste groeivorm van de soort: emergent, drijvend-bebladerd, volledig drijvend en ondergedoken (Cronk \& Fennessey 2016). Emergente planten hebben een sterke binding met het terrestrische milieu; ze wisselen zuurstof en koolzuur uit met de lucht, assimileren boven het waterniveau en nemen voedingsstoffen op uit de bodem. Ondergedoken planten nemen daarentegen zuurstof, koolzuur en bicarbonaat op uit de waterkolom. Ook wortelen ze vaak in de bodem, waar ze ook de benodigde voedingsstoffen uit kunnen halen, terwijl micronutriënten uit de waterkolom kunnen worden opgenomen (Barko \& Smart 1980). Sommige soorten zijn volledig zwevend en nemen alleen stoffen op uit de waterkolom. Drijvend-bebladerde soorten hebben drijvende bladeren en wortelen in de bodem, waaruit ze voedingsstoffen opnemen, terwijl ze met huidmondjes aan het oppervlak zuurstof en koolzuur met de lucht uitwisselen. Drijvende macrofyten nemen stoffen op uit de waterkolom en uit de lucht. De groeivorm is dus belangrijk bij de interpretatie voor een diagnose. 
Ondergedoken of submerse macrofyten reageren duidelijk maar zeer variabel op eutrofiëring (Søndergaard et al. 2010). Op basis van een analyse van de indicatorwaarde voor eutrofiëring van submerse macrofyten op basis van gegevens uit 300 Deense meren bleek dat de meeste soorten voorkwamen binnen een grote range van fosfor- en chlorofyl-a concentraties. Uitzonderingen waren enkele soorten isoëtiden (Lobelia, Isoëtes) en Potamogeton-soorten ( $P$. gramineus, $P$. alpinus en $P$. filiformis), allen indicatief voor lage nutriëntenconcentraties. Zelfs de vaak als eutrofie-indicator beschouwde soorten Elodea canadensis en Potamogeton pectinatus kwamen ook voor bij lage P-concentraties ( TP $<0,02 \mathrm{mg} \mathrm{P} / \mathrm{L}$, Chla $<5 \mu \mathrm{g} / \mathrm{L}$ ) en bleken niet echt indicatief. Wel waren bedekking en plantvolume negatief gecorreleerd met nutriëntenconcentraties. Søndergaard et al. (2010) concludeerden dat alleen grote veranderingen in de soortensamenstelling van submerse macrofyten op basis van soortenrijkdom, aanwezigheid van indicatorsoorten, bedekking en maximale diepte van voorkomen een indicatie van eutrofiëring geven. Dit bevestigt het beeld wat ook al was gegeven door Sand-Jensen et al. (2008), Kosten et al. (2009), Lauridsen et al. (2003), Jeppesen et al., (2005), Lacoul \& Freedman (2006) en Hilt et al. (2006) en is strijdig met o.a. Coops et al. (2007) en Penning et al. (2008). Al met al zijn er maar weinig ondergedoken macrofyten indicatief voor trofiegraad, maar wel voor bijvoorbeeld grootte van het water (Duarte \& Kalff 1986a). Drijvende macrofyten geven een vrij generieke indicatie van eutrofiëring en domineren alleen bij hoge nutriëntenconcentraties (Poikane et al. 2018).

Demars \& Edwards (2009) kwamen voor stromende wateren tot vergelijkbare conclusies. Op basis van de respons van 110 macrofytensoorten verspreid over 161 locaties in circumneutrale en alkalische stromende wateren bleken lokale milieu-omstandigheden en ruimtelijke beperkingen niet te onderscheiden. Demars \& Edwards (2009) concludeerden dat de macrofytensamenstelling geen betrouwbare bio-indicatie geeft van de trofiestatus.

Macrofyten reageren echter wel op een aantal andere stressoren. Emergente macrofyten reageren bijvoorbeeld op peilfluctuatie (Toivonen \& Nybom 1989, Rørslett 1991, Partanen \& Hellsten 2005), landgebruik (Kurimo 1970, Uotila 1971, Churski 1983, Pieczyńska et al. 1988, Naumenko et al. 2000, Egertson et al. 2004), fysieke stress van golven en wind (Segal 1971, Keddy 1983, Weisner 1991, Riis \& Hawes 2003), oeverhelling (Duarte \& Kalff 1986b), bodemsamenstelling (Barko \& Smart 1983), maaibeheer (Mäemets \& Freiberg 2004) en begrazing (Uotila 1971, Meriläinen \& Toivonen 1979, Weisner 1987, Mäemets \& Freiberg 2004). Alahuhta et al. (2011) concludeerden op basis van onderzoek in 848 stroomgebieden dat landgebruik, klimaat en geomorfologie bepalend waren voor het voorkomen van emergente macrofyten. Juist de combinatie van deze factoren maakt emergente soorten minder geschikt voor chemische stressindicatie en meer voor grootschalige, lange termijn processen.

Samenvattend blijkt dat slechts de afwezigheid van enkele soorten macrofyten stress door eutrofiëring indiceert (isoëtiden en bepaalde fonteinkruiden; Carbiener et al. 1990, Muller 1990) of bij een toename van de nutriënten het verschijnen en of sterk uitbreiden. Andere soorten zijn indicatief voor andere omgevingsfactoren, zoals Nuphar lutea indicatief voor de typologische factoren diepte en langzame stroming (Haslam 1978). Het is van groot belang bij het gebruik van macrofyten voor diagnose dat onderscheid wordt gemaakt tussen de typologische en stress indicerende factoren (Grasmück et al. 1995).

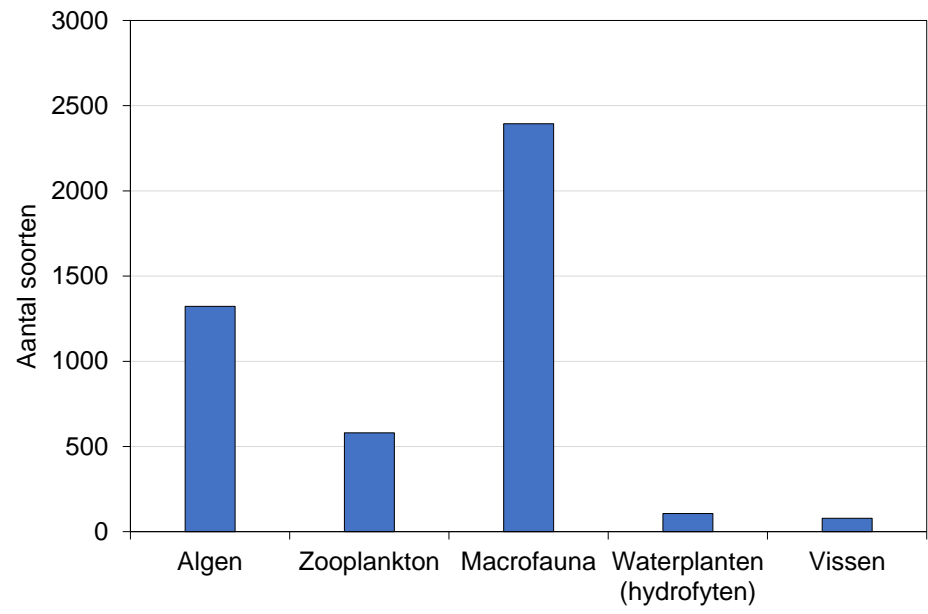


Figuur 5: Aantal soorten per hoofdgroep van aquatische organismen.

\subsubsection{Macroinvertebraten}

Macroinvertebraten zijn de meest gebruikte indicatorgroep in het waterbeheer. De belangrijkste redenen hiervoor zijn 1.) het grote aantal soorten dat op een locatie kan worden aangetroffen (Figuur 5), 2.) de grote variatie aan habitats die ze bezetten en 3.) het grote aantal rollen dat ze in het ecosysteem functioneren vervullen. Zo spelen macroinvertebraten een essentiële rol in voedselwebben, ze nemen verschillende trofische posities in, zorgen voor trofische interacties en verwerken een breed scala aan voedseltypen (dood en levend organisch materiaal, micro- en mesofauna, algen en soms waterplanten). Daarnaast zijn macroinvertebraten het sterkst gerelateerd aan milieuomstandigheden op de schaal van een traject of compartiment en, afhankelijk van de groep, de habitat daarbinnen en het landschap daar omheen (Dovciak \& Perry 2002, Feld \& Hering 2007, Lammert \& Allan 1999, Richards et al. 1993, 1997, Waite 2014). Ook vormen macroinvertebraten een belangrijke voedselbron voor o.a. vissen en vogels. Door het hoge aantal (duizenden) soorten met een grote taxonomische en fylogenetische diversiteit omvatten ze een breed palet aan indicatieve waarden. De verschillende systematische groepen indiceren ieder verschillende milieu-omstandigheden met verschillende toleranties voor stressoren. Macroinvertebraten accumuleren giftige stoffen, die in het dier detecteerbaar zijn, terwijl ze dat niet zijn in het water. Tenslotte zijn ze zijn relatief snel te bemonsteren en zijn veel groepen relatief eenvoudig te identificeren.

De lengte van de levenscyclus van macroinvertebraten varieert van dagen tot jaren en neemt daarmee een intermediaire positie in t.o.v. andere organismegroepen. Daarmee omvatten het een grote variatie aan tijdsperioden en dus een grote variatie in snelle tot langzame respons op veranderingen in milieuomstandigheden.De mate van generieke verstoring is met macroinvertebraten gemakkelijk te bepalen (Danecker 1986, Hellawell 1986, Moog 1988, Metcalfe 1989, Rosenberg \& Resh 1992, Metcalfe-Smith 1994, Ollis et al. 2006, Moog et al. 2018). De verschillen in indicatieve waarde van macroinvertebraten zijn groot. Zo worden bijvoorbeeld aquatische Hemiptera nauwelijks als indicator gebruikt omdat ze breed verspreid voorkomen, een grote verspreidingscapaciteit bezitten en per soort een breed scala aan habitats bewonen (ubiquisten; Taybi et al. 2021), de nimfen echter zijn meer indicatief. Tegelijk zijn er ook binnen deze groep enkele soorten die wel een indicatieve waarde hebben, zoals Cymatia bonsdorffi, Glaenocorisa propinqua, Notonecta obliqua en $N$. reuteri (zuur, voedselarm water; Higler 1979). Coleoptera (kevers) zijn bijvoorbeeld meer geschikt omdat er meer specialisten in deze groep te vinden zijn (Eyre \& Foster 1989), terwijl Ephemeroptera, Plecoptera en Trichoptera, zogenaamde EPT-taxa, zeer veel als indicator worden gebruikt. Binnen de EPT is voor Nederland de Trichoptera de belangrijkste groep voor diagnose en voorspelling door het grote aantal soorten dat in de Nederlandse wateren te vinden is.

Samenvattend maakt de intermediaire lengte van de levenscyclus en de beperktere ruimtelijke verspreiding en de grote variatie aan soorten met verschillende habitateisen macroinvertebraten tot een bij uitstek geschikte groep voor stressindicatie, m.a.w. diagnose en voorspelling.

\subsubsection{Vissen}

Vissen in stromende wateren reageren sterk op hydrologische omstandigheden, zoals afvoerdynamiek en overstromingsregime (Welcomme \& Halls 2001, 2004, Bunn \& Arthington 2002) en morfologische veranderingen, zoals de beschikbaarheid van habitats, oeverdegradatie en verlies van connectiviteit (Belpaire et al. 2000, Degerman et al. 2001). Visindices kunnen ook de mate van eutrofiëring (Mehner et al. 2007, Argillier et al. 2013), verzuring (Henriksen et al. 1989) en multiple stress in stromende wateren aangeven (Whittier 1999). Indien meren vooraf worden ingedeeld naar diepte en morfologie, dan kan ook de mate van eutrofiëring aan de hand van de vissamenstelling worden beoordeeld (Garcia et al. 2006). Echter heeft deze benadering geen algemene geldigheid (Bachmann et al. 1996).

Het gebruik van vissamenstelling als indicator ondervindt een aantal problemen: de aanpassing aan een natuurlijke variatie in grootte, diepte, habitats (Grandmottet 1983) en waterchemie en de capaciteit om stress te vermijden (grootschalige mobiliteit) van de vissen zelf, het uitzetten van vis en het introduceren van exotische soorten door de mens, en methodisch een grote verscheidenheid aan bemonsteringsmethoden. Wel kan het ontbreken van lengte- of leeftijdsklassen in de populatieopbouw of juist oververtegenwoordiging van bepaalde klassen, gewicht (Nash et al. 2006), conditie (Bolger \& Connolly 1989) of energiegehalte, vaak vetten, (Cargnelli et al. 1997) informatie geven over voedselbeschikbaarheid en predatiedruk. Daarnaast integreren vissen, als organismen hoog in de voedselpiramide, vaak de directe 
en indirecte effecten van multiple stress (habitatverlies, oeveraantasting, peilregulatie, eutrofiëring) op lagere trofische niveaus. Daardoor zijn er ook maar een beperkt aantal significante relaties tussen vissamenstelling en specifieke stressoren aangetoond (Welcomme 1979, Hugueny 1989, Oberdorff et al. 1995, Olin et al. 2013). Als generieke stressindicator is vis wel geschikt gebleken (Aubry \& Elliott 2006) en vaak wordt het alternatief gezocht in het gebruik van gildes (Welcomme et al. 2006).

Samenvattend bepaalt hun grootschalige mobiliteit dat vissen als actieve verspreiders beter grootschalige ruimtelijke patronen in omgevingsvariabelen weergeven, die op hun beurt vooral bepaald worden door aquatische verbindingen, m.a.w. de landschapscontext (Beisner et al. 2006, Shurin et al. 2009).

\subsubsection{Zoöplankton}

Zoöplankton is geen KRW-organismegroep maar is een belangrijk onderdeel van het pelagisch voedselweb in meren (Jeppesen et al. 2011). Volgens deze auteurs bevat het zoöplankton sterkere indicatorwaarden t.o.v. vissen en algen, behoeft minder inspanning en kan uitgevoerd worden tegen lagere kosten. Daarnaast is zoöplankton beter geschikt om de effecten van herstelmaatregelen in meren te evalueren. De meerwaarde van zoöplankton als indicator is een gevolg van hun positie in het voedselweb, ingeklemd tussen de top-down regulatoren (vissen) en bottom-up factoren (fytoplankton). Hiermee geeft zoöplankton informatie over het relatieve belang van top-down en bottom-up processen en hebben ze grote effecten op de helderheid van het water. Jeppesen et al. (2011) stellen wel dat algen- en vismonitoring niet kan worden vervangen door zoöplankton. $\mathrm{Er}$ is echter een kostbaar vismonitoringprogramma nodig om hetzelfde inzicht te krijgen in de trofische dynamiek die zoöplankton op een meer kosteneffectieve manier kan bieden.

Bodembewonende zoöplanktontaxa zijn talrijk en geven nog meer informatie (Jeppesen et al. 2001a,b; Davidson et al. 2007). Ze kunnen dienen als indicator van zowel pelagisch en benthische processen.

Zoöplankton is, ondanks een brede verspreiding langs de eutrofiëringsgradiënt geschikt gebleken om eutrofiëring (Haberman 1998, Jeppesen et al. 2000), te indiceren en vooral de oligotrofe versus sterk eutrofe omstandigheden. M.a.w. niet de soorten zelf maar afgeleide parameters zijn bruikbaar als indicator, bijvoorbeeld afmeting, aandeel grote soorten, en de zoöplankton:fytoplankton ratio (García-Chicote et al. 2018) voor top-down processen en biomassa, aandeel rotiferen en aandeel calanoïde copepoden, en aantal eieren (Caroni \& Irvine 2010) voor bottom-up processen (Jeppesen et al. 2011).

Tenslotte ontwikkelden Kuczyńska-Kippen et al. (2020) een trait-gebaseerde beoordeling voor zoöplankton.

\subsection{Keuze van een aquatische indicatorgroep}

\subsubsection{Complementariteit}

Uit een aantal studies is in het afgelopen decennium gebleken dat de soortenrijkdom en de variatie in taxonsamenstelling tussen verschillende taxonomische groepen (diatomeeën/algen, zoöplankton, macrofyten, macroinvertebraten, vissen) doorgaans onderling relatief zwak, voor minder dan de helft, onderling gecorreleerd zijn, wat geldt voor zowel stromende als stilstaande wateren (Heino 2010). M.a.w. de relaties tussen de soortensamenstelling en het milieu blijken verschillend voor de verschillende bestudeerde organismegroepen (Paavola et al. 2003, Mykrä et al. 2012, Heino et al. 2005, Grenouillet et al. 2008). Dit verschil is hiervoor in paragraaf 6.3 ook al geduid.

Ook wordt aangenomen dat grote organismen sterker reageren op grootschalige omgevingsvariatie (bijvoorbeeld landgebruik, klimaat) dan kleine organismen, die sterk reageren op lokale (kleine schaal) omstandigheden (bijvoorbeeld waterchemie, habitatheterogeniteit). Zo zijn bijvoorbeeld vissen nauwer geassocieerd met de morfometrie van meren en ongewervelden met habitatheterogeniteit en waterchemie (Jackson \& Harvey 1993). Aangezien verschillende taxonomische groepen verschillend reageren op ecologische stressoren op verschillende schalen in ruimte en tijd is het van belang om meerdere taxonomische groepen te betrekken in een diagnose. Hierbij is de complementaire informatie die de verschillende organismegroepen geven van belang. Wanneer echter het effect van een bepaalde stressor gediagnosticeerd moet worden, dan kan op basis van de te verwachten respons de meest indicatieve organismegroep zorgvuldig worden gekozen (Allen et al. 1999a,b, Baldi 2003, Johnson \& Hering 2009). Dergelijke keuzes zijn nodig om doelgericht en kosteneffectief te opereren. 
Het blijkt dat bacteriën nog niet veel worden gebruikt. Bacteriën zijn vooral gerelateerd aan de chemische waterkwaliteit. Met de toenemende kennis van DNA-sequencing komt het identificeren van bacteriën tot op soortniveau steeds sneller dichterbij. Bacteriën vertonen ook een sterke congruentie, m.a.w. er kan vaak volstaan worden met een hoog taxonomisch niveau. Algen zijn geschikte indicatoren om de lokale, korte-termijn effecten van nutriënten en eutrofiëring te diagnosticeren. Voor diatomeeën, eveneens vaak gerelateerd aan chemische waterkwaliteit, is genusniveau vaak voldoende. Het voordeel van de bioindicatie van macrofyten is de lange-termijn indicatie van de effecten van nutriëntenbelasting en van stressoren die op oevervorm en peil inwerken. Macroinvertebraten zijn geschikte indicatoren van (organische) vervuiling en hydrologische en morfologische verstoringen op habitatschaal. Vissen zijn geschikte indicatoren om de effecten van hydromorfologische tekorten op de biotoopschaal en vooral de verstoringen van de laterale en longitudinale connectiviteit tot op de schaal van het stroomgebied te bepalen.

\subsubsection{Taxonomisch niveau}

Soorten worden beschouwd als de belangrijkste eenheden van biodiversiteit (Gaston, 2000). Biologische beoordeling is vaak gebaseerd op informatie op soortniveau (Birk et al. 2012) maar kan ook hogere taxonomische niveaus worden gebruikt (Jones 2008). In het algemeen is de respons van soorten op veranderingen in de omgeving het meest indicatief op soortniveau (Warwick 1993, Bevilacqua et al. 2012). Afhankelijk van de biologische groep kost het gebruik van informatie op soortniveau echter meestal meer tijd, geld en expertise dan dat van hogere taxonomische niveaus (Warwick 1993, Bertrand et al. 2006). Het te kiezen taxonomische niveau hangt af de vereisten van het onderzoek (Ellis 1985). Hierbij speelt wel de vraag welke informatie al op een hoger taxonomisch niveau beschikbaar is. Als het hogere taxonomische niveau (geslacht of familie) daadwerkelijk patronen op soortniveau vertegenwoordigd (d.w.z. congruentie binnen het taxon; Bertrand et al. 2006) dan kan daarmee worden volstaan (Heino \& Soininen 2007, Terlizzi et al. 2009, Mueller et al. 2013). Indien volstaan kan worden met een hoger taxonomisch niveau kan meer tijd besteed worden aan het vaker bemonsteren van meer locaties (grotere temporele en ruimtelijke resolutie; Mueller et al. 2013). Vooralsnog is het gebruik van soortniveau voor de diagnose het meest geschikt. 


\section{Hoe verder?}

\subsection{Benodigde informatie}

De soortensamenstelling op een locatie is steeds mede afhankelijk van bijvoorbeeld de ruimtelijke en temporele heterogeniteit van de aanwezige habitat, de ouderdom van het water, historische gebeurtenissen, prioriteitseffecten (soorte die eerder zijn gearriveerd voorkomen dat andere soorten kunnen koloniseren), de regionale soortenpoule, de 'milieu'filters en intrinsieke factoren zoals stochasticiteit en dominantie (Weiher et al. 2011, Hille Ris Lambers et al. 2012). Om van de soortensamenstelling op een locatie een diagnose af te leiden is daarom inzicht nodig in een groot aantal aspecten (Lake et al. 2007, HilleRislambers et al. 2012):

- De actueel aanwezige soorten en hun indicatie (preferentie en aversie) van de milieuomstandigheden op de locatie over verschillende schalen in ruimte en tijd (landschapstype, watertype, habitat) m.a.w. de ecologische preferenties van de aanwezige soorten, bij voorkeur per levensstadium.

- De regionale, lokale en habitat 'milieufilters'.

- De samenstelling van de regionale soortenpoule, m.a.w. de lijst met potentiële soorten die voor zouden kunnen komen.

- $\quad$ De biologische aanpassingen van de aanwezige en potentiële soorten, bijvoorbeeld voedselvoorkeur, gedrag, levenscycluskenmerken en mobiliteit.

- De biologische interacties tussen de aanwezige soorten, bijvoorbeeld de intra- en interspecifieke interacties zoals competitie, predatie, mutualisme en commensalisme.

- De dispersiecapaciteit van soorten in de regionale soortenpoule en de eisen die gesteld worden aan het te overbruggen gebied.

- De soortensamenstelling van het streefbeeld of de referentiesituatie.

- De historische nalatenschap.

- De mate van connectiviteit en milieukwaliteit in het landschap (de biogeografische regio van de soortenpoule).

Bovenstaande maakt duidelijk dat het lokaal samen voorkomen van soorten van belang is, maar roept tegelijk de vraag op hoe deze informatie te verzamelen en wat met de kennis van nu al mogelijk is.

Hoe kan, in het licht van het bovenstaande, een diagnose en omgekeerd het vinden van geschikte indicatoren het beste wordt aangepakt? In ieder geval dienen alle eerdergenoemde aspecten voor het identificeren van indicatoren meegenomen te worden. Dit kan worden samengevat als het verzamelen van kennis over de functionele relaties van soorten(-groepen) met abiotische en biotische omgeving, kennis van die omgeving (en de historie daarvan) en kennis over de natuurlijke situatie.

Het opbouwen van kennis over de functionele relaties van soorten met de abiotische en biotische omgeving staat centraal. Er is al decennia veel gepubliceerd over de levenskenmerken van soorten (zie ook §4.1). Hieruit is wel duidelijk geworden dat niet alle biologische kenmerken bekend hoeven te zijn om te komen tot een set functionele kenmerken. Ecologisch preferenties zijn een stap in de goede richting maar behoeven: 1.) een verbetering van de indicatiewaarden, en 2.) een aanvulling op de aspecten biologische aanpassingen, interacties met andere soorten, en dispersie-/connectiviteitskenmerken. Deze functionele relaties kunnen in het regionale, lokale en habitat 'milieufilters' raamwerk worden geplaatst en per regio (regionale milieukenmerken, watertype en regionale soortenpoules) in relatie tot de referentiesituatie en de historie van een watersysteem worden uitgewerkt.

\subsection{Informatiebronnen}

Indicatie (preferentie en aversie) van milieu-omstandigheden Zie paragraaf 6.2 . 
Biologische aanpassingen van de aanwezige en potentiële soorten.

Zie paragraaf 6.2 .

De samenstelling van de regionale soortenpoule.

De regionale soortenpoule is de cumulatieve lijst van soorten aanwezig in het te bestuderen stroomgebied/hydrologische eenheid en de zone daarom heen die in afstand afhangt van de gebruikte organismegroep. In de SESA benadering hanteren we een gebied van 5-15 km vanaf een beeksysteem voor macroinvertebraten (zie ook Sundermann et al. (2011)). Stoll et al. (2013) komen bij terugkeer van vissoorten na herstel eveneens tot circa $5 \mathrm{~km}$ binnen een laaglandbeekstroomgebied. Echter, het watertype, de mate van isolatie en de dispersiecapaciteit kunnen tot grote verschillen in overbrugbare afstanden leiden. Voor helofyten en hydrofyten komen Vermonden et al. (2010) bijvoorbeeld tot respectievelijk 30 en $20 \mathrm{~km}$. In alle gevallen moet dus rekening worden gehouden met de soorten in kwestie, de afstand tot bronpopulaties, de mate van connectiviteit en de tijdspanne waarbinnen soorten terug zouden moeten kunnen keren. Op dit vlak zijn nog veel kennishiaten. De genoemde afstanden moeten dus als indicatief worden beschouwd.

De biologische interacties tussen de aanwezige soorten.

Naast het gebruik van de informatie benoemd in paragraaf 6.2 kan hier een ecologische netwerkanalyse voor de regio waarbinnen het stroomgebied valt worden uitgevoerd. Hiervoor zijn rekenpakketten beschikbaar zoals het package 'netassoc' binnen het programmapakket $R$ ( $R$ is een softwarepakket en programmeertaal ontwikkeld voor statistiek en data-analysedoeleinden).

De dispersiecapaciteit van soorten in de regionale soortenpoule.

Over de dispersiecapaciteit van veel soorten is nog weinig informatie beschikbaar. Soms worden indicaties gegeven in de bronnen genoemd in paragraaf 6.2. Nader onderzoek is hier nodig.

De soortensamenstelling van het streefbeeld of de referentiesituatie.

Hiervoor zijn verschillende mogelijkheden, variërend van het gebruik van de aquatische natuurdoeltypen, (regionale) referentiebeschrijvingen tot het vaststellen van de regionale potentiële soortenpoule op basis van monitoringsdata (zie ook hieronder).

\section{De historische nalatenschap.}

Om een beeld te krijgen van de ontwikkelingen over de laatste decennia (20-40 jaar) zijn vaak monitoringsgegevens en andere onderzoeken van het stroomgebied beschikbaar. Dit gaat meestal terug tot eind jaren ' 70 begin jaren ' 80 van de vorige eeuw. Om nog verder terug te kunnen gaan kan historisch onderzoek in archieven of musea behulpzaam zijn.

De regionale, lokale en habitat 'milieufilters'.

Kennis van de milieu-omstandigheden, de ecologische sleutelfactoren en DPSIR-ketens, in het te bestuderen stroomgebied/hydrologische eenheid is noodzakelijk.

De mate van connectiviteit en milieukwaliteit in het landschap.

Afhankelijk van organismegroep kunnen kaarten met (potentiële) dispersiebarrières of juist dispersiecorridors worden gebruikt, afgeleid van bijvoorbeeld kaarten van het watersysteem (legger) of landgebruikskaarten. 


\section{Literatuur}

Alahuhta, J., Ecke, F., Johnson, L. B., Sass, L., \& Heino, J. (2017). A comparative analysis reveals little evidence for niche conservatism in aquatic macrophytes among four areas on two continents. Oikos, 126(1), 136-148.

Alahuhta, J., Vuori, K. M., \& Luoto, M. (2011). Land use, geomorphology and climate as environmental determinants of emergent aquatic macrophytes in boreal catchments.

Allan, J. D. (2004). Landscapes and riverscapes: the influence of land use on stream ecosystems. Annu. Rev. Ecol. Evol. Syst., 35, 257-284.

Allen, A. P., Whittier, T. R., Kaufmann, P. R., Larsen, D. P., O'Connor, R. J., Hughes, R. M., ... \& Paulsen, S. G. (1999b). Concordance of taxonomic richness patterns across multiple assemblages in lakes of the northeastern United States. Canadian Journal of Fisheries and Aquatic Sciences, 56(5), 739747.

Allen, A. P., Whittier, T. R., Larsen, D. P., Kaufmann, P. R., O'Connor, R. J., Hughes, R. M., ... \& Paulsen, S. G. (1999a). Concordance of taxonomic composition patterns across multiple lake assemblages: effects of scale, body size, and land use. Canadian Journal of Fisheries and Aquatic Sciences, 56(11), 2029-2040.

Ángeles-González, L. E., Martínez-Meyer, E., Yañez-Arenas, C., Velázquez-Abunader, I., Garcia-Rueda, A., Díaz, F., ... \& Rosas, C. (2020). Using realized thermal niche to validate thermal preferences from laboratory studies. How do they stand?. Ecological Indicators, 118, 106741.

Angermeier, P. L., \& Schlosser, I. J. (1989). Species-area relationship for stream fishes. Ecology, 70(5), 1450-1462.

Araújo, M. B., \& Rozenfeld, A. (2014). The geographic scaling of biotic interactions. Ecography, 37(5), 406415.

Araújo, M. B., Alagador, D., Cabeza, M., Nogués-Bravo, D., \& Thuiller, W. (2011). Climate change threatens European conservation areas. Ecology letters, 14(5), 484-492.

Argillier, C., Caussé, S., Gevrey, M., Pédron, S., De Bortoli, J., Brucet, S., ... \& Holmgren, K. (2013). Development of a fish-based index to assess the eutrophication status of European lakes. Hydrobiologia, 704(1), 193-211.

Arita, T., Suzuki, R., \& Chiba, N. (2016, July). How ecological inheritance can affect the evolution of complex niche construction in a 2D physical simulation. In Proceedings of the Artificial Life Conference 201613 (pp. 426-433). One Rogers Street, Cambridge, MA 02142-1209 USA journalsinfo@ mit. edu: MIT Press.

Asaeda, T., Manatunge, J., Roberts, J., \& Hai, D. N. (2006). Seasonal dynamics of resource translocation between the aboveground organs and age-specific rhizome segments of Phragmites australis. Environmental and Experimental Botany, 57(1-2), 9-18.

Astorga, A., Heino, J., Luoto, M., \& Muotka, T. (2011). Freshwater biodiversity at regional extent: determinants of macroinvertebrate taxonomic richness in headwater streams. Ecography, 34(5), 705-713.

Astorga, A., Oksanen, J., Luoto, M., Soininen, J., Virtanen, R., \& Muotka, T. (2012). Distance decay of similarity in freshwater communities: do macro-and microorganisms follow the same rules?. Global Ecology and Biogeography, 21(3), 365-375.

Aubry, A., \& Elliott, M. (2006). The use of environmental integrative indicators to assess seabed disturbance in estuaries and coasts: application to the Humber Estuary, UK. Marine Pollution Bulletin, 53(1-4), 175-185.

Bachmann, R. W., Jones, B. L., Fox, D. D., Hoyer, M., Bull, L. A., \& Canfield, Jr, D. E. (1996). Relations between trophic state indicators and fish in Florida (USA) lakes. Canadian Journal of Fisheries and Aquatic Sciences, 53(4), 842-855.

Báldi, A. (2003). Using higher taxa as surrogates of species richness: a study based on 3700 Coleoptera, Diptera, and Acari species in Central-Hungarian reserves. Basic and applied Ecology, 4(6), 589593.

Barko, J. W., \& Smart, R. M. (1980). Mobilization of sediment phosphorus by submersed freshwater macrophytes. Freshwater Biology, 10(3), 229-238.

Barko, J. W., \& Smart, R. M. (1983). Effects of organic matter additions to sediment on the growth of aquatic plants. The journal of Ecology, 161-175. 
Barrett, S. C., Eckert, C. G., \& Husband, B. C. (1993). Evolutionary processes in aquatic plant populations. Aquatic Botany, 44(2-3), 105-145.Bêche, L. A., \& Statzner, B. (2009). Richness gradients of stream invertebrates across the USA: taxonomy-and trait-based approaches. Biodiversity and Conservation, 18(14), 3909-3930.

Beisner, B. E., Peres-Neto, P. R., Lindström, E. S., Barnett, A., \& Longhi, M. L. (2006). The role of environmental and spatial processes in structuring lake communities from bacteria to fish. Ecology, 87(12), 2985-2991.

Belpaire, C., Smolders, R., Auweele, I. V., Ercken, D., Breine, J., Van Thuyne, G., \& Ollevier, F. (2000). An Index of Biotic Integrity characterizing fish populations and the ecological quality of Flandrian water bodies. Hydrobiologia, 434(1), 17-33.

Bennett, J.R., Cumming, B.F., Ginn, B.K. \& Smol, J.P. (2010). Broad-scale environmental response and niche conservatism in lacustrine diatom communities. Global Ecology and Biogeography, 19, 724732.

Berggren, $\AA$. (2001). Persistence of introduced populations of Roesel's bush-cricket Metrioptera roeseli in a patchy landscape (No. 197).

Bertrand, Y., Pleijel, F., \& Rouse, G. W. (2006). Taxonomic surrogacy in biodiversity assessments, and the meaning of Linnaean ranks. Systematics and Biodiversity, 4(2), 149-159.

Bevilacqua, S., Sandulli, R., Plicanti, A., \& Terlizzi, A. (2012). Taxonomic distinctness in Mediterranean marine nematodes and its relevance for environmental impact assessment. Marine pollution bulletin, 64(7), 1409-1416.

Biggs, B. J. (1995). The contribution of flood disturbance, catchment geology and land use to the habitat template of periphyton in stream ecosystems. Freshwater biology, 33(3), 419-438.

Birk, S., Bonne, W., Borja, A., Brucet, S., Courrat, A., Poikane, S., ... \& Hering, D. (2012). Three hundred ways to assess Europe's surface waters: an almost complete overview of biological methods to implement the Water Framework Directive. Ecological indicators, 18, 31-41.

Blackburn, T. M., Gaston, K. J., \& Loder, N. (1999). Geographic gradients in body size: a clarification of Bergmann's rule. Diversity and distributions, 5(4), 165-174.

Blick, R., \& Burns, K. C. (2009). Network properties of arboreal plants: are epiphytes, mistletoes and lianas structured similarly?. Perspectives in Plant Ecology, Evolution and Systematics, 11(1), 41-52.

Bloemendaal F. H. J. L. \& Roelofs, J. G. M. (1988). Waterplanten en waterkwaliteit (p. 189). F. H. J. L. Bloemendaal (Ed.). Utrecht: Koninklijke Nederlandse Natuurhistorische Vereniging.

Blois, J. L., Gotelli, N. J., Behrensmeyer, A. K., Faith, J. T., Lyons, S. K., Williams, J. W., ... \& Wing, S. (2014). A framework for evaluating the influence of climate, dispersal limitation, and biotic interactions using fossil pollen associations across the late Quaternary. Ecography, 37(11), 10951108.

Bolger, T., \& Connolly, P. L. (1989). The selection of suitable indices for the measurement and analysis of fish condition. Journal of Fish Biology, 34(2), 171-182.

Bolnick, D. I., Amarasekare, P., Araújo, M. S., Bürger, R., Levine, J. M., Novak, M., ... \& Vasseur, D. A. (2011). Why intraspecific trait variation matters in community ecology. Trends in ecology $\&$ evolution, 26(4), 183-192.

Bonada, N., Prat, N., Resh, V. H., \& Statzner, B. (2006). Developments in aquatic insect biomonitoring: a comparative analysis of recent approaches. Annu. Rev. Entomol., 51, 495-523.

Bowler, D. E., \& Benton, T. G. (2005). Causes and consequences of animal dispersal strategies: relating individual behaviour to spatial dynamics. Biological reviews, 80(2), 205-225.

Briske, D. D., Fuhlendorf, S. D., \& Smeins, F. E. (2006). A unified framework for assessment and application of ecological thresholds. Rangeland Ecology \& Management, 59(3), 225-236.

Brown, J. H., Gillooly, J. F., Allen, A. P., Savage, V. M., \& West, G. B. (2004). Toward a metabolic theory of ecology. Ecology, 85(7), 1771-1789.

Brown, J. H., Stevens, G. C., \& Kaufman, D. M. (1996). The geographic range: size, shape, boundaries, and internal structure. Annual review of ecology and systematics, 27(1), 597-623.

Bruelheide, H. (2000). A new measure of fidelity and its application to defining species groups. Journal of Vegetation science, 11(2), 167-178.

Bruun, H.H. \& Poschold, P. (2006). Why are small seeds dispersed through animal guts: large numbers or seed size per se? Oikos, 113, 402- 411.

Buckley, L. B., Ehrenberger, J. C., \& Angilletta Jr, M. J. (2015). Thermoregulatory behaviour limits local adaptation of thermal niches and confers sensitivity to climate change. Functional Ecology, 29(8), 1038-1047.

Bunn, S. E., \& Arthington, A. H. (2002). Basic principles and ecological consequences of altered flow regimes for aquatic biodiversity. Environmental management, 30(4), 492-507. 
Calabrese, J. M., Certain, G., Kraan, C., \& Dormann, C. F. (2014). Stacking species distribution models and adjusting bias by linking them to macroecological models. Global Ecology and Biogeography, 23(1), 99-112.

Callaway, R. M., Brooker, R. W., Choler, P., Kikvidze, Z., Lortie, C. J., Michalet, R., ... \& Cook, B. J. (2002). Positive interactions among alpine plants increase with stress. Nature, 417(6891), 844-848.

Carbiener, R., Trémolières, M., Mercier, J. L., \& Ortscheit, A. (1990). Aquatic macrophyte communities as bioindicators of eutrophication in calcareous oligosaprobe stream waters (Upper Rhine plain, Alsace). Vegetatio, 86(1), 71-88.

Cargnelli, L. M., \& Gross, M. R. (1997). Fish energetics: larger individuals emerge from winter in better condition. Transactions of the American Fisheries Society, 126(1), 153-156.

Carlisle, D. M., Meador, M. R., Moulton II, S. R., \& Ruhl, P. M. (2007). Estimation and application of indicator values for common macroinvertebrate genera and families of the United States. Ecological indicators, $7(1), 22-33$.

Caroni, R. \& K. Irvine (2010). The potential of zooplankton communities for ecological assessment of lakes: redundant concept or political oversight? Biology and Environment: Proceedings of the Royal Irish Academy 110B: 35-53.Afkhami, M. E., Rudgers, J. A., \& Stachowicz, J. J. (2014). Multiple mutualist effects: conflict and synergy in multispecies mutualisms. Ecology, 95(4), 833-844.

Centraal Bureau voor de Statistiek (1991). Botanisch basisregister. Voorburg/Heerlen.

Charvet, S., Statzner, B., Usseglio-Polatera, P., \& Dumont, B. (2000). Traits of benthic macroinvertebrates in semi-natural French streams: an initial application to biomonitoring in Europe. Freshwater Biology, 43(2), 277-296.

Chesson, P. (2000a). Mechanisms of maintenance of species diversity. Annual review of Ecology and Systematics, 31(1), 343-366.

Chesson, P. (2000b). General theory of competitive coexistence in spatially-varying environments. Theoretical population biology, 58(3), 211-237.

Churski, Z. (1983). Eutrophication and the disappearance of lakes in the Brodnica Lake District, Northern Poland as a result of human interference. Hydrobiologia, 103(1), 165-168.

Coesel P. F. M. (1998) Sieralgen en Natuurwaarden. Uitgeverij Koninklijke Nederlandse Natuurhistorische Vereniging, Utrecht.

Colling M. (1996) Ökologische Typisierung der aquatischen Makrofauna. Informationsberichte des Bayerischen Landesamtes für Wasserwirtschaft. München, Germany.

Connor, E. F. \& D. Simberloff 1979. The assembly of species communities: Chance or competition? Ecology 60: $1132-1140$.

Coops, H., Kerkum, F. C. M., Van den Berg, M. S., \& Van Splunder, I. (2007). Submerged macrophyte vegetation and the European Water Framework Directive: assessment of status and trends in shallow, alkaline lakes in the Netherlands. In Shallow Lakes in a Changing World (pp. 395-402). Springer, Dordrecht.

Cornell, H. V., \& Harrison, S. P. (2014). What are species pools and when are they important?. Annual Review of Ecology, Evolution, and Systematics, 45, 45-67.

Cottenie, K. (2005). Integrating environmental and spatial processes in ecological community dynamics. Ecology letters, 8(11), 1175-1182.

Cronk, J. K., \& Fennessy, M. S. (2016). Wetland plants: biology and ecology. CRC press.

Culp, J. M., Armanini, D. G., Dunbar, M. J., Orlofske, J. M., Poff, N. L., Pollard, A. I., ... \& Hose, G. C. (2011). Incorporating traits in aquatic biomonitoring to enhance causal diagnosis and prediction. Integrated environmental assessment and management, 7(2), 187-197.

Dalla Vecchia, A., Villa, P., \& Bolpagni, R. (2020). Functional traits in macrophyte studies: Current trends and future research agenda. Aquatic Botany, 103290.

Damschen, E. I., Brudvig, L. A., Haddad, N. M., Levey, D. J., Orrock, J. L., \& Tewksbury, J. J. (2008). The movement ecology and dynamics of plant communities in fragmented landscapes. Proceedings of the National Academy of Sciences, 105(49), 19078-19083.

Danecker, E. (1986). Makrozoobenthos-Proben in der biologischen Gewässeranalyse. Wasser und Abwasser, 30, 325-406.

Davidson, T., C. Sayer, M. Perrow, M. Bramm \& E. Jeppesen (2007). Are the controls of species composition similar for contemporary and sub-fossil cladoceran assemblages? A study of 39 shallow lakes of contrasting trophic status. Journal of Paleolimnology 38: 117-134.

Davis ,W. S. (1995). Biological assessment and criteria: Building on the past. In Davis WS, Simon TP, eds, Biological Assessment and Criteria: Tools for Water Resource Planning and Decision Making. Lewis, Boca Raton, FL, USA, pp 7-14. 
De Bie, T., De Meester, L., Brendonck, L., Martens, K., Goddeeris, B., Ercken, D., ... \& Declerck, S. A. J. (2012). Body size and dispersal mode as key traits determining metacommunity structure of aquatic organisms. Ecology letters, 15(7), 740-747.

De Lyon, M. J. H., \& Roelofs, J. G. M. (1986). Waterplanten in relatie tot waterkwaliteit en bodemgesteldheid. Katholieke Universiteit, Laboratorium voor Aquatische Oecologie.

De Marco Jr, P., Diniz-Filho, J. A. F., \& Bini, L. M. (2008). Spatial analysis improves species distribution modelling during range expansion. Biology letters, 4(5), 577-580.

de Vries J. (2021). Biology-based approaches to unravel multiple stressor impacts on aquatic ecosystems. Thesis University of Amsterdam.

Degerman, E., Hammar, J., Nyberg, P., \& Svärdson, G. (2001). Human impact on the fish diversity in the four largest lakes of Sweden. AMBIO: A Journal of the Human Environment, 30(8), 522-528.

Demars, B. O., \& Edwards, A. C. (2009). Distribution of aquatic macrophytes in contrasting river systems: a critique of compositional-based assessment of water quality. Science of the Total Environment, 407(2), 975-990.

DÍAZ, A. M., ALONSO, M. L. S., \& GUTIÉRREZ, M. R. V. A. (2008). Biological traits of stream macroinvertebrates from a semi-arid catchment: patterns along complex environmental gradients. Freshwater Biology, 53(1), 1-21.

Dodson, S. I., Arnott, S. E., \& Cottingham, K. L. (2000). The relationship in lake communities between primary productivity and species richness. Ecology, 81(10), 2662-2679.

Dolédec, S., Phillips, N., Scarsbrook, M., Riley, R. H., \& Townsend, C. R. (2006). Comparison of structural and functional approaches to determining landuse effects on grassland stream invertebrate communities. Journal of the North American Benthological Society, 25(1), 44-60.

Dolédec, S., Statzner, B., \& Bournard, M. (1999). Species traits for future biomonitoring across ecoregions: patterns along a human-impacted river. Freshwater Biology, 42(4), 737-758.

Dovciak, A. L., \& Perry, J. A. (2002). In search of effective scales for stream management: does agroecoregion, watershed, or their intersection best explain the variance in stream macroinvertebrate communities?. Environmental Management, 30(3), 365-377.

Duarte, C. M., \& Kalff, J. (1986b). Littoral slope as a predictor of the maximum biomass of submerged macrophyte communities 1, 1. Limnology and Oceanography, 31(5), 1072-1080.

Duarte, C. M., Kalff, J., \& Peters, R. H. (1986a). Patterns in biomass and cover of aquatic macrophytes in lakes. Canadian Journal of Fisheries and Aquatic Sciences, 43(10), 1900-1908.

Durand, A. M., Peeters, E. T. H. M., \& Wortelboer, F. G. (1998). Effectmodule regionale watersystemen, fase 1: Soortbenadering. STOWA rapport 98-W-02, $106 \mathrm{pp}$.

Egertson, C. J., Kopaska, J. A., \& Downing, J. A. (2004). A century of change in macrophyte abundance and composition in response to agricultural eutrophication. Hydrobiologia, 524(1), 145-156.

Eiler, A., Langenheder, S., Bertilsson, S., \& Tranvik, L. J. (2003). Heterotrophic bacterial growth efficiency and community structure at different natural organic carbon concentrations. Applied and environmental microbiology, 69(7), 3701-3709.

Ejrnæs, R., Bruun, H. H., \& Graae, B. J. (2006). Community assembly in experimental grasslands: suitable environment or timely arrival?. Ecology, 87(5), 1225-1233.

Ellenberg, H., \& Leuschner, C. (2010). Vegetation Mitteleuropas mit den Alpen: in ökologischer, dynamischer und historischer Sicht (Vol. 8104). Utb. Boek

Elliott, J. M. (1981). Some aspects of thermal stress on freshwater teleosts. In Stress and fish (A. D. Pickering, pp. 209-245). London, United Kingdom: Academic Press.

Ellis, D. 1985. Taxonomic sufficiency in pollution assessment. Mar. Pollut. Bull. 16: 459.

Elmqvist, T., Folke, C., Nyström, M., Peterson, G., Bengtsson, J., Walker, B., \& Norberg, J. (2003). Response diversity, ecosystem change, and resilience. Frontiers in Ecology and the Environment, 1(9), 488-494.

Ertsen, D., Verdonschot, P., Wortelboer, R. \& van der Wal, B. (2007). RISTORI: modellen voor het voorspellen van de effecten van maatregelen op de aquatische gemeenschappen van sloten en beken. STOWA rapport 2007-15, 12 pp.

Eyre, M. D., \& Foster, G. N. (1989). A comparison of aquatic Heteroptera and Coleoptera communities as a basis for environmental and conservation assessments in static water sites. Journal of Applied Entomology, 108(1-5), 355-362.

Fahrig, L., \& Merriam, G. (1994). Conservation of fragmented populations. Conservation biology, 8(1), 5059.

Feld, C. K., \& Hering, D. (2007). Community structure or function: effects of environmental stress on benthic macroinvertebrates at different spatial scales. Freshwater Biology, 52(7), 1380-1399. 
Fenchel, T. O. M., \& Finlay, B. J. (2004). The ubiquity of small species: patterns of local and global diversity. Bioscience, 54(8), 777-784.

Fierer, N., \& Jackson, R. B. (2006). The diversity and biogeography of soil bacterial communities. Proceedings of the National Academy of Sciences, 103(3), 626-631.

Fierer, N., Bradford, M. A., \& Jackson, R. B. (2007). Toward an ecological classification of soil bacteria. Ecology, 88(6), 1354-1364.

Finlay, B. J. (2002). Global dispersal of free-living microbial eukaryote species. science, 296(5570), 10611063.

Franken, R.J.M., Gardeniers J.J.P. \& Peeters, E.T.H.M. (2006). Handboek Nederlandse ecologische beoordelingssystemen (EBEO-systemen). Deel A. Filosofie en beschrijving van de systemen. Stowa rapport 2006-04., 255 pp.

Garcia, X. F., Diekmann, M., Brämick, U., Lemcke, R., \& Mehner, T. (2006). Correlations between typeindicator fish species and lake productivity in German lowland lakes. Journal of Fish Biology, 68(4), 1144-1157.

Gaston, K. J. (2000). Global patterns in biodiversity. Nature, 405(6783), 220-227.

Gaudard, A., Weber, C., Alexander, T. J., Hunziker, S., \& Schmid, M. (2018). Impacts of using lakes and rivers for extraction and disposal of heat. Wiley Interdisciplinary Reviews: Water, 5(5), e1295 (18 pp.). https://doi.org/10.1002/wat2.1295

Gayraud, S., Statzner, B., Bady, P., Haybachp, A., Schöll, F., Usseglio-Polatera, P., \& Bacchi, M. (2003). Invertebrate traits for the biomonitoring of large European rivers: an initial assessment of alternative metrics. Freshwater Biology, 48(11), 2045-2064.

Geismar, J., Haase, P., Nowak, C., Sauer, J., \& Pauls, S. U. (2015). Local population genetic structure of the montane caddisfly $D$ rusus discolor is driven by overland dispersal and spatial scaling. Freshwater Biology, 60(1), 209-221.

Girvan, M., \& Newman, M. E. (2002). Community structure in social and biological networks. Proceedings of the national academy of sciences, 99(12), 7821-7826.

Gotelli, N. J. (2000). Null model analysis of species co-occurrence patterns. Ecology, 81(9), 2606-2621.

Gotelli, N. J., Graves, G. R., \& Rahbek, C. (2010). Macroecological signals of species interactions in the Danish avifauna. Proceedings of the National Academy of Sciences, 107(11), 5030-5035.

Göthe, E., Baattrup-Pedersen, A., Wiberg-Larsen, P., Graeber, D., Kristensen, E. A., \& Friberg, N. (2017). Environmental and spatial controls of taxonomic versus trait composition of stream biota. Freshwater Biology, 62(2), 397-413.

Göthe, E., Baattrup-Pedersen, A., Wiberg-Larsen, P., Graeber, D., Kristensen, E. A., \& Friberg, N. (2017). Environmental and spatial controls of taxonomic versus trait composition of stream biota. Freshwater Biology, 62(2), 397-413.

Grasmück, N., Haury, J., Léglize, L., \& Muller, S. (1995). Assessment of the bio-indicator capacity of aquatic macrophytes using multivariate analysis. Hydrobiologia, 300(1), 115-122.

Gregory, S. V., Swanson, F. J., McKee, W. A., \& Cummins, K. W. (1991). An ecosystem perspective of riparian zones. BioScience, 41(8), 540-551.

Grenouillet, G., Brosse, S., Tudesque, L., Lek, S., Baraillé, Y., \& Loot, G. (2008). Concordance among stream assemblages and spatial autocorrelation along a fragmented gradient. Diversity and Distributions, 14(4), 592-603.

Griffith, B., Scott, J. M., Carpenter, J. W., \& Reed, C. (1989). Translocation as a species conservation tool: status and strategy. Science, 245(4917), 477-480.

Guisan, A., \& Rahbek, C. (2011). SESAM-a new framework integrating macroecological and species distribution models for predicting spatio-temporal patterns of species assemblages. Journal of Biogeography (J. Biogeogr.), 38, 1433-1444.

Haberman, J. (1998). Zooplankton of Lake Võrtsjärv. Limnologica 28: 49-65.

Hamilton, A. T., Schäfer, R. B., Pyne, M. I., Chessman, B., Kakouei, K., Boersma, K. S., ... \& Stamp, J. (2020). Limitations of trait-based approaches for stressor assessment: The case of freshwater invertebrates and climate drivers. Global change biology, 26(2), 364-379.

Hampton, S. E., Galloway, A. W., Powers, S. M., Ozersky, T., Woo, K. H., Batt, R. D., ... \& Xenopoulos, M. A. (2017). Ecology under lake ice. Ecology letters, 20(1), 98-111.

Haslam, S. M., 1978. River plants. The macrophytic vegetation of watercourses. Cambridge Univ. Press, London, $367 \mathrm{pp}$.

Heino, J. (2010). Are indicator groups and cross-taxon congruence useful for predicting biodiversity in aquatic ecosystems?. Ecological Indicators, 10(2), 112-117.

Heino, J., \& Soininen, J. (2007). Are higher taxa adequate surrogates for species-level assemblage patterns and species richness in stream organisms?. Biological Conservation, 137(1), 78-89. 
Heino, J., Soininen, J., Lappalainen, J., \& Virtanen, R. (2005). The relationship between species richness and taxonomic distinctness in freshwater organisms. Limnology and Oceanography, 50(3), 978986.

Hellawell, J. M. (1986). Biological indicators. In Biological Indicators of Freshwater Pollution and Environmental Management (pp. 45-77). Springer, Dordrecht.

Heneghan, P.A., Biggs, J., Jepson, P.C., Kedwards, T., Maund, S.J., Sherratt, T.N., Shillabeer, N., Stickland, T.R. \& Williams, P. (1999) Pond-FX: ecotoxicology from $\mathrm{pH}$ to population recovery [online]. 1st edition. Oregon State University: Department of Entomology. http://www.ent.orst.edu/PondFX >.

Henriksen, A., Lien, L., Rosseland, B. O., Traaen, T. S., \& Sevaldrud, I. S. (1989). Lake acidification in Norway: present and predicted fish status. Ambio, 314-321.

Hering, D., Johnson, R. K., Kramm, S., Schmutz, S., Szoszkiewicz, K., \& Verdonschot, P. F. (2006). Assessment of European streams with diatoms, macrophytes, macroinvertebrates and fish: a comparative metric-based analysis of organism response to stress. Freshwater biology, 51(9), 1757-1785.

Higler, L. G. (1979). Limnological data on a Dutch moorland pool through sixty years. Hydrobiological Bulletin, 13(2), 138-143.

HilleRisLambers, J., Adler, P. B., Harpole, W. S., Levine, J. M., \& Mayfield, M. M. (2012). Rethinking community assembly through the lens of coexistence theory. Annual review of ecology, evolution, and systematics, 43, 227-248.

Hilt, S., Gross, E. M., Hupfer, M., Morscheid, H., Mählmann, J., Melzer, A., ... \& Van de Weyer, K. (2006). Restoration of submerged vegetation in shallow eutrophic lakes-A guideline and state of the art in Germany. Limnologica, 36(3), 155-171.

Holt, R. D. (1996). Adaptive evolution in source-sink environments: direct and indirect effects of densitydependence on niche evolution. Oikos, 182-192.

Holt, R. D., Barfield, M., \& Gomulkiewicz, R. (2004). Temporal variation can facilitate niche evolution in harsh sink environments. The American Naturalist, 164(2), 187-200.

Huey, R. B., Hertz, P. E., \& Sinervo, B. (2003). Behavioral drive versus behavioral inertia in evolution: a null model approach. The American Naturalist, 161(3), 357-366.

Hugueny, B. (1989). West African rivers as biogeographic islands: species richness of fish communities. Oecologia, 79(2), 236-243.

Hynes, H. B. N., \& Hynes, H. B. N. (1970). The ecology of running waters (Vol. 555). Liverpool: Liverpool University Press.

Jaarsma, N.G. (2016). Vergelijkende analyse milieuindicatiewaarden macrofyten. Stowa rapport 2016-W$03,25 \mathrm{pp}$.

Jackson, D. A., \& Harvey, H. H. (1993). Fish and benthic invertebrates: community concordance and community-environment relationships. Canadian Journal of Fisheries and Aquatic Sciences, 50(12), 2641-2651.

Jenkins, D. G., Brescacin, C. R., Duxbury, C. V., Elliott, J. A., Evans, J. A., Grablow, K. R., ... \& Williams, S. E. (2007). Does size matter for dispersal distance?. Global Ecology and Biogeography, 16(4), 415-425.

Jeppesen, E., J. P. Jensen, C. Jensen, B. Faafeng, P. Brettum, D. Hessen, M. Søndergaard, T. Lauridsen \& K. Christoffersen, 2003a. The impact of nutrient state and lake depth on top-down control in the pelagic zone of lakes: study of 466 lakes from the temperate zone to the Arctic. Ecosystems 6 : 313-325.

Jeppesen, E., J. P. Jensen, M. Søndergaard, T. L. Lauridsen \& F. Landkildehus, 2000. Trophic structure, species richness and biodiversity in Danish Lakes: changes along a phosphorus gradient. Freshwater Biology 45: 201-218.

Jeppesen, E., J. P. Jensen, T. L. Lauridsen, S. L. Amsinck, K. Christoffersen, M. Søndergaard \& S. F. Mitchell, 2003b. Sub-fossils of cladocerans in the surface sediment of 135 lakes as proxies for community structure of zooplankton, fish abundance and lake temperature. Hydrobiologia 491: 1573-5117.

Jeppesen, E., Noges, P., Davidson, T. A., Haberman, J., Noges, T., Blank, K., ... \& Amsinck, S. L. (2011). Zooplankton as indicators in lakes: a scientific-based plea for including zooplankton in the ecological quality assessment of lakes according to the European Water Framework Directive (WFD). Hydrobiologia, 676(1), 279-297.

Jeppesen, E., Peder Jensen, J., Søndergaard, M., Lauridsen, T., \& Landkildehus, F. (2000). Trophic structure, species richness and biodiversity in Danish lakes: changes along a phosphorus gradient. Freshwater biology, 45(2), 201-218. 
Jeppesen, E., Søndergaard, M., Jensen, J. P., Havens, K. E., Anneville, O., Carvalho, L., ... \& Winder, M. (2005). Lake responses to reduced nutrient loading-an analysis of contemporary long-term data from 35 case studies. Freshwater biology, 50(10), 1747-1771.

Johnson, R. K., \& Hering, D. (2009). Response of taxonomic groups in streams to gradients in resource and habitat characteristics. Journal of Applied Ecology, 46(1), 175-186.

Jones, C. G., Lawton, J. H., \& Shachak, M. (1994). Organisms as ecosystem engineers. Samson F. B. \& Knopf F. L. (eds), Ecosystem management: 130-147.

Jones, F. C. (2008). Taxonomic sufficiency: the influence of taxonomic resolution on freshwater bioassessments using benthic macroinvertebrates. Environmental Reviews, 16(NA), 45-69.

Jonsson, T., Cohen, J. E., \& Carpenter, S. R. (2005). Food webs, body size, and species abundance in ecological community description. Advances in ecological research, 36(36), 1-84.

Keddy, P. A. (1983). Shoreline vegetation in Axe Lake, Ontario: effects of exposure on zonation patterns. Ecology, 64(2), 331-344.

Keizer-Vlek, H. E., \& Verdonschot, P. F. M. (2007). Gebruikersinstructie voor de ecologische karakterisering van oppervlaktewateren (EKO 4.7) (No. 1509). Alterra.

Kissling, W. D., Dormann, C. F., Groeneveld, J., Hickler, T., Kühn, I., McInerny, G. J., ... \& O’Hara, R. B. (2012). Towards novel approaches to modelling biotic interactions in multispecies assemblages at large spatial extents. Journal of Biogeography, 39(12), 2163-2178.

Knillmann, S., Orlinskiy, P., Kaske, O., Foit, K., \& Liess, M. (2018). Indication of pesticide effects and recolonization in streams. Science of the total environment, 630, 1619-1627.

Korhonen, J. J., Soininen, J., \& Hillebrand, H. (2010). A quantitative analysis of temporal turnover in aquatic species assemblages across ecosystems. Ecology, 91(2), 508-517.

Kosten, S., Kamarainen, A. M. Y., Jeppesen, E., van Nes, E. H., Peeters, E. T., Mazzeo, N., ... \& Scheffer, M. (2009). Climate-related differences in the dominance of submerged macrophytes in shallow lakes. Global Change Biology, 15(10), 2503-2517.

Kristiansen, J. (1996). 16. Dispersal of freshwater algae - a review. Hydrobiologia, 336(1), 151-157.

Krynak, E. M., \& Yates, A. G. (2018). Benthic invertebrate taxonomic and trait associations with land use in an intensively managed watershed: Implications for indicator identification. Ecological Indicators, 93, 1050-1059.

Kurimo, U. (1970, January). Effect of pollution on the aquatic macroflora of the Varkaus area, Finnish Lake District. In Annales Botanici Fennici (pp. 213-254). Societas Biologica Fennica Vanamo.

Lacoul, P., \& Freedman, B. (2006). Relationships between aquatic plants and environmental factors along a steep Himalayan altitudinal gradient. Aquatic Botany, 84(1), 3-16.

Lake, P. S. (2000). Disturbance, patchiness, and diversity in streams. Journal of the north american Benthological society, 19(4), 573-592.

Lake, P. S., Bond, N., \& Reich, P. (2007). Linking ecological theory with stream restoration. Freshwater biology, 52(4), 597-615.

Lammert, M., \& Allan, J. D. (1999). Assessing biotic integrity of streams: effects of scale in measuring the influence of land use/cover and habitat structure on fish and macroinvertebrates. Environmental management, 23(2), 0257-0270.

Lancaster, J., \& Downes, B. J. (2010). Linking the hydraulic world of individual organisms to ecological processes: putting ecology into ecohydraulics. River Research and Applications, 26(4), 385-403.

Larsen, S., \& Ormerod, S. J. (2014). Anthropogenic modification disrupts species co-occurrence in stream invertebrates. Global change biology, 20(1), 51-60.

Lasky, J. R., Uriarte, M., Boukili, V. K., \& Chazdon, R. L. (2014). Trait-mediated assembly processes predict successional changes in community diversity of tropical forests. Proceedings of the National Academy of Sciences, 111(15), 5616-5621.

Lauridsen, T. L., Jensen, J. P., Jeppesen, E., \& Søndergaard, M. (2003). Response of submerged macrophytes in Danish lakes to nutrient loading reductions and biomanipulation. Hydrobiologia, 506(1), 641-649.

Leibold, M. A., \& Miller, T. E. (2004). From metapopulations to metacommunities. Ecology, genetics and evolution of metapopulations, 133-150.

Leibold, M. A., Holyoak, M., Mouquet, N., Amarasekare, P., Chase, J. M., Hoopes, M. F., ... \& Gonzalez, A. (2004). The metacommunity concept: a framework for multi-scale community ecology. Ecology letters, 7(7), 601-613.

Lepistö, L. (1999). Phytoplankton assemblages reflecting the ecological status of lakes in Finland. Finnish Environment Institute.

Lévêque, C. (2003). Ecology: from ecosystem to biosphere. Science Publishers. 
Liess, M., \& Ohe, P. C. V. D. (2005). Analyzing effects of pesticides on invertebrate communities in streams. Environmental Toxicology and Chemistry: An International Journal, 24(4), 954-965.

Lindström, E. S., Forslund, M., Algesten, G., \& Bergström, A. K. (2006). External control of bacterial community structure in lakes. Limnology and oceanography, 51(1), 339-342.

Loreau, M., Naeem, S., Inchausti, P., Bengtsson, J., Grime, J. P., Hector, A., .. \& Wardle, D. A. (2001). Biodiversity and ecosystem functioning: current knowledge and future challenges. science, 294(5543), 804-808.

Mäemets, H., \& Freiberg, L. (2004). Characteristics of reeds on Lake Peipsi and the floristic consequences of their expansion. Limnologica, 34(1-2), 83-89.

Magnuson, J. J., Crowder, L. B., \& Medvick, P. A. (1979). Temperature as an ecological resource. American Zoologist, 19(1), 331-343.

Martiny, J. B. H., Bohannan, B. J., Brown, J. H., Colwell, R. K., Fuhrman, J. A., Green, J. L., ... \& Staley, J. T. (2006). Microbial biogeography: putting microorganisms on the map. Nature Reviews Microbiology, 4(2), 102-112.

Marzin, A., Archaimbault, V., Belliard, J., Chauvin, C., Delmas, F., \& Pont, D. (2012). Ecological assessment of running waters: do macrophytes, macroinvertebrates, diatoms and fish show similar responses to human pressures?. Ecological indicators, 23, 56-65.

Mbaka, J. G., \& Wanjiru Mwaniki, M. (2015). A global review of the downstream effects of small impoundments on stream habitat conditions and macroinvertebrates. Environmental Reviews, 23(3), 257-262.

McGill, B. J., Enquist, B. J., Weiher, E., \& Westoby, M. (2006). Rebuilding community ecology from functional traits. Trends in ecology \& evolution, 21(4), 178-185.

Mehner, T., Holmgren, K., Lauridsen, T. L., Jeppesen, E., \& Diekmann, M. (2007). Lake depth and geographical position modify lake fish assemblages of the European 'Central Plains' ecoregion. Freshwater biology, 52(11), 2285-2297.

Meriläinen, J., \& Toivonen, H. (1979, January). Lake Keskimmäinen, dynamics of vegetation in a small shallow lake. In Annales Botanici Fennici (pp. 123-139). Finnish Botanical Publishing Board.

Merritt, R. W., Cummins \& K. W., Berg, M. B. (2008) An introduction to the aquatic insects of North America. Kendall/Hunt, Dubuque, Iowa, 4th edition.

Metcalfe, J. L. (1989). Biological water quality assessment of running waters based on macroinvertebrate communities: history and present status in Europe. Environmental pollution, 60(1-2), 101-139.

Metcalfe-Smith, J. L. (1994). Biological water-quality assessment of rivers: use of macroinvertebrate communities. The rivers handbook: hydrological and ecological principles, 144-170.

Montoya, J. M., Pimm, S. L., \& Solé, R. V. (2006). Ecological networks and their fragility. Nature, 442(7100), 259-264.

Moog, O. (1988). Die Bodenfauna der Mühlviertier Fließgewässer. Mühlviertel. Natur, Kultur, Leben, 209218.

Moog, O. (1995) Fauna aquatica Austriaca. Katalog zur autokologischen Einstufung aquatischer Organismen Osterreichs. Wien.

Moog, O., Schmutz, S., \& Schwarzinger, I. (2018). Biomonitoring and bioassessment. Riverine Ecosystem Management, 371.

Morueta-Holme, N., Blonder, B., Sandel, B., McGill, B. J., Peet, R. K., Ott, J. E., ... Svenning, J.-C. (2016). A network approach for inferring species associations from co-occurrence data. Ecography, 39(12), 139-1150. https ://doi.org/10.1111/ecog.01892

Mouillot, D., Graham, N. A., Villéger, S., Mason, N. W., \& Bellwood, D. R. (2013). A functional approach reveals community responses to disturbances. Trends in ecology \& evolution, 28(3), 167-177.

Mouquet, N., \& Loreau, M. (2003). Community patterns in source-sink metacommunities. The american naturalist, 162(5), 544-557.

Mueller, M., Pander, J., \& Geist, J. (2013). Taxonomic sufficiency in freshwater ecosystems: effects of taxonomic resolution, functional traits, and data transformation. Freshwater Science, 32(3), 762778.

Muller, S. (1990) Une séquence de groupements végétaux bioindicateurs d'eutrophisation croissante des cours d'eau faiblement minéralisés des Basses Vosges gréseuses du Nord. Comptes Rendus de l'Académie des Sciences Paris 310, 509-14.

Mykrä, H., Saarinen, T., Tolkkinen, M., McFarland, B., Hämäläinen, H., Martinmäki, K., \& Kløve, B. (2012). Spatial and temporal variability of diatom and macroinvertebrate communities: how representative are ecological classifications within a river system?. Ecological Indicators, 18, 208-217. 
Nash, R. D., Valencia, A. H., \& Geffen, A. J. (2006). The origin of Fulton's condition factor-setting the record straight. Fisheries, 31(5), 236-238.

Naumenko, M. A., Avinsky, V. A., Barbashova, M. A., Guzivaty, V. V., Karetnikov, S. G., Kapustina, L. L., ... \& Chernykh, O. A. (2000). Current ecological state of the Volkhov Bay of the Ladoga Lake. Ecol. Chem, 9, 75-87.

Newman, M. E. J. (2018). Networks. An introduction. Oxford University Press Inc., New York.

Niemi, A., Melvasalo, T. \& Heinonen, P. 1985. Phytoplankton counting techniques and primary production measurements - comments on the results of intercalibration. Aqua Fennica 15: 89-103.

Noble, R. A. A., Cowx, I. G., Goffaux, D., \& Kestemont, P. (2007). Assessing the health of European rivers using functional ecological guilds of fish communities: standardising species classification and approaches to metric selection. Fisheries Management and Ecology, 14(6), 381-392.

Normand, S., Ricklefs, R. E., Skov, F., Bladt, J., Tackenberg, O., \& Svenning, J. C. (2011). Postglacial migration supplements climate in determining plant species ranges in Europe. Proceedings of the Royal Society B: Biological Sciences, 278(1725), 3644-3653.

Norton, S. B., Cormier, S. M., Smith, M., \& Jones, R. C. (2000). Can biological assessments discriminate among types of stress? A case study from the Eastern Corn Belt Plains ecoregion. Environmental Toxicology and Chemistry: An International Journal, 19(4), 1113-1119.

Noyola, J., Caamal-Monsreal, C., Díaz, F., Re, D., Sanchez, A., \& Rosas, C. (2013). Thermopreference, tolerance and metabolic rate of early stages juvenile Octopus maya acclimated to different temperatures. Journal of thermal biology, 38(1), 14-19.

Oberdorff T., Guégan J.F., Hugueny B. (1995) Global scale patterns of fish species richness in rivers. Ecography, 18, 345- 352.

Oberdorff, T., Pont, D., Hugueny, B., \& Porcher, J. P. (2002). Development and validation of a fish-based index for the assessment of 'river health'in France. Freshwater Biology, 47(9), 1720-1734.

Olden, J. D., Jackson, D. A., \& Peres-Neto, P. R. (2001). Spatial isolation and fish communities in drainage lakes. Oecologia, 127(4), 572-585.

Olin, M., Rask, M., Ruuhijärvi, J., \& Tammi, J. (2013). Development and evaluation of the Finnish fishbased lake classification method. Hydrobiologia, 713(1), 149-166.

Ollis, D. J., Dallas, H. F., Esler, K. J., \& Boucher, C. (2006). Bioassessment of the ecological integrity of river ecosystems using aquatic macroinvertebrates: an overview with a focus on South Africa. African Journal of Aquatic Science, 31(2), 205-227.

Ortega-Mayagoitia, E., Hernández-Martínez, O., \& Ciros-Pérez, J. (2018). Phenotypic plasticity of lifehistory traits of a calanoid copepod in a tropical lake: Is the magnitude of thermal plasticity related to thermal variability?. PLoS One, 13(4), e0196496.

Paavola, R., Muotka, T., Virtanen, R., Heino, J., \& Kreivi, P. (2003). Are biological classifications of headwater streams concordant across multiple taxonomic groups?. Freshwater Biology, 48(10), 1912-1923.

Pace, M. L., Findlay, S. E., \& Lints, D. (1992). Zooplankton in advective environments: the Hudson River community and a comparative analysis. Canadian Journal of Fisheries and Aquatic Sciences, 49(5), 1060-1069.

Padisák, J., L. O. Crossetti \& L. Naselli-Flores, 2009. Use and misuse in the application of the phytoplankton functional classification: a critical review with updates. Hydrobiologia 621: 1-19.

Partanen, S., \& Hellsten, S. (2005). Changes of emergent aquatic macrophyte cover in seven large boreal lakes in Finland with special reference to water level regulation. Fennia-International Journal of Geography, 183(1), 57-79.

Partanen, S., Luoto, M., \& Hellsten, S. (2009). Habitat level determinants of emergent macrophyte occurrence, extension and change in two large boreal lakes in Finland. Aquatic Botany, 90(3), 261268.

Pearman, P. B., Guisan, A., Broennimann, O., \& Randin, C. F. (2008). Niche dynamics in space and time. Trends in ecology \& evolution, 23(3), 149-158.

Penning, W. E., Mjelde, M., Dudley, B., Hellsten, S., Hanganu, J., Kolada, A., ... \& Ecke, F. (2008). Classifying aquatic macrophytes as indicators of eutrophication in European lakes. Aquatic ecology, 42(2), 237-251.

Peters, R. H., \& Peters, R. H. (1986). The ecological implications of body size (Vol. 2). Cambridge university press.

Peters, R. H., \& Wassenberg, K. (1983). The effect of body size on animal abundance. Oecologia, 60(1), 89-96.

Petersen, I., Masters, Z., Hildrew, A. G., \& Ormerod, S. J. (2004). Dispersal of adult aquatic insects in catchments of differing land use. Journal of Applied Ecology, 41(5), 934-950. 
Petersen, I., Masters, Z., Ormerod, S. J., \& Hildrew, A. G. (2006). Sex ratio and maturity indicate the local dispersal and mortality of adult stoneflies. Freshwater Biology, 51(8), 1543-1551.

Pieczyńska, E., Ozimek, T., \& Rybak, J. I. (1988). Long-term changes in littoral habitats and communities in Lake Mikolajskie (Poland). Internationale Revue der gesamten Hydrobiologie und Hydrographie, 73(4), 361-378.

Pimm, S. L. \& Rice, J. A. (1987). The dynamics of multispecies, multi-life-stage models of aquatic food webs. Theor. Popul. Biol. 32, 303--325.

Poff, N. L., \& Ward, J. V. (1990). Physical habitat template of lotic systems: recovery in the context of historical pattern of spatiotemporal heterogeneity. Environmental management, 14(5), 629.

Poff, N. L., Olden, J. D., Vieira, N. K., Finn, D. S., Simmons, M. P., \& Kondratieff, B. C. (2006). Functional trait niches of North American lotic insects: traits-based ecological applications in light of phylogenetic relationships. Journal of the North American Benthological Society, 25(4), 730-755.

Poff, N. L., Pyne, M. I., Bledsoe, B. P., Cuhaciyan, C. C., \& Carlisle, D. M. (2010). Developing linkages between species traits and multiscaled environmental variation to explore vulnerability of stream benthic communities to climate change. Journal of the North American Benthological Society, 29(4), 1441-1458.

Poikane, S., Portielje, R., Denys, L., Elferts, D., Kelly, M., Kolada, A., ... \& van den Berg, M. S. (2018). Macrophyte assessment in European lakes: Diverse approaches but convergent views of 'good'ecological status. Ecological indicators, 94, 185-197.

Poole, G. C., \& Berman, C. H. (2001). An ecological perspective on in-stream temperature: natural heat dynamics and mechanisms of human-caused thermal degradation. Environmental management, 27(6), 787-802.

Porter, S. D. (2008). Algal attributes: an autecological classification of algal taxa collected by the National Water-Quality Assessment Program. Reston, VA: US Geological Survey.

Pörtner, H. O., \& Farrell, A. P. (2008). Physiology and climate change. Science, 690-692.

Pottier, J., Dubuis, A., Pellissier, L., Maiorano, L., Rossier, L., Randin, C. F., ... \& Guisan, A. (2013). The accuracy of plant assemblage prediction from species distribution models varies along environmental gradients. Global Ecology and Biogeography, 22(1), 52-63.

Quak, J. (1994). De visstand in stromende wateren. In Vismigratie, Visgeleiding en Vispassages in Nederland, Raat AJP (ed.). Organisation for the Improvement of Inland Fisheries: Nieuwegein; 59-84.

Resh, V. H. (2008). Which group is best? Attributes of different biological assemblages used in freshwater biomonitoring programs. Environmental Monitoring and Assessment, 138(1), 131-138.

Reynolds, C. S. (2012). Environmental requirements and habitat preferences of phytoplankton: chance and certainty in species selection. Botanica Marina 55 (2012): 1-17

Reynolds, C. S., V. Huszar, C. Kruk, L. Naselli-Flores \& S. Melo, 2002. Towards a functional classification of the freshwater phytoplankton. Journal of Plankton Research24: 417-428.

Richards, C., Haro, R., Johnson, L., \& Host, G. (1997). Catchment and reach-scale properties as indicators of macroinvertebrate species traits. Freshwater Biology, 37(1), 219-230.

Richards, C., Host, G. E., \& Arthur, J. W. (1993). Identification of predominant environmental factors structuring stream macroinvertebrate communities within a large agricultural catchment. Freshwater Biology, 29(2), 285-294.

Riis, T., \& Hawes, I. A. N. (2003). Effect of wave exposure on vegetation abundance, richness and depth distribution of shallow water plants in a New Zealand lake. Freshwater Biology, 48(1), 75-87.

Rørslett, B. (1991). Principal determinants of aquatic macrophyte richness in northern European lakes. Aquatic Botany, 39(1-2), 173-193.

Rosenberg, D.M. \& Resh, V.H. 1992. Introduction to Freshwater Biomonitoring and Benthic Macroinvertebrates. In Freshwater Biomonitoring and Benthic Macroinvertebrates (D.M. Rosenberg \& V.H. Resh, eds). Chapman and Hall, New York, p.1-10.

Sand-Jensen, K., Pedersen, N. L., Thorsgaard, I., Moeslund, B., Borum, J., \& Brodersen, K. P. (2008). 100 years of vegetation decline and recovery in Lake Fure, Denmark. Journal of Ecology, 96(2), 260271.

Sarremejane, R., Cid, N., Stubbington, R., Datry, T., Alp, M., Cañedo-Argüelles, M., ... \& Bonada, N. (2020). DISPERSE, a trait database to assess the dispersal potential of European aquatic macroinvertebrates. Scientific data, 7(1), 1-9.

Schaminée, J. H. J., Weeda, E. J., \& Westhoff, V. (1995). De vegetatie van Nederland. Deel 2: Plantengemeenschappen van wateren, moerassen en natte heiden. Opulus. 
Schaumburg, J., Schranz, C., Foerster, J., Gutowski, A., Hofmann, G., Meilinger, P., ... \& Schmedtje, U. (2004). Ecological classification of macrophytes and phytobenthos for rivers in Germany according to the Water Framework Directive. Limnologica, 34(4), 283-301.

Schleuning, M., Fründ, J., Klein, A. M., Abrahamczyk, S., Alarcón, R., Albrecht, M., ... \& Blüthgen, N. (2012). Specialization of mutualistic interaction networks decreases toward tropical latitudes. Current biology, 22(20), 1925-1931.

Schmidt-Kloiber, A., \& Hering, D. (2015). www. freshwaterecology. info-An online tool that unifies, standardises and codifies more than 20,000 European freshwater organisms and their ecological preferences. Ecological indicators, 53, 271-282.

Schoener, T. W., \& Schoener, A. (1983). The time to extinction of a colonizing propagule of lizards increases with island area. Nature, 302(5906), 332-334.

Schoener, T. W., \& Spiller, D. A. (1995). Effect of predators and area on invasion: an experiment with island spiders. Science, 267(5205), 1811-1813.

Science Advisory Board (1993). Evaluation of draft technical guidance on biological criteria for streams and small rivers. EPASAB-EPEC-94. U.S. Environmental Protection Agency, Washington, DC.

Sculthorpe, C. D. (1967). Biology of aquatic vascular plants. FAO, St. Martin's Press. 523-580.

Segal, S. (1971). Principles of structure, zonation and succession of aquatic macrophytes. Hidrobiologia, Bucuresti, 12 (1971), pp. 89-95.

Shurin, J. B., Cottenie, K., \& Hillebrand, H. (2009). Spatial autocorrelation and dispersal limitation in freshwater organisms. Oecologia, 159(1), 151-159.

Soberón, J., \& Nakamura, M. (2009). Niches and distributional areas: concepts, methods, and assumptions. Proceedings of the National Academy of Sciences, 106(Supplement 2), 19644-19650.

Soininen, J., Paavola, R., \& Muotka, T. (2004). Benthic diatom communities in boreal streams: community structure in relation to environmental and spatial gradients. Ecography, 27(3), 330-342.

Søndergaard, M., Johansson, L. S., Lauridsen, T. L., JøRGENSEN, T. B., Liboriussen, L., \& Jeppesen, E. (2010). Submerged macrophytes as indicators of the ecological quality of lakes. Freshwater Biology, 55(4), 893-908.

Søndergaard, M., Johansson, L. S., Lauridsen, T. L., jørgensen, T. B., Liboriussen, L., \& Jeppesen, E. (2010). Submerged macrophytes as indicators of the ecological quality of lakes. Freshwater Biology, 55(4), 893-908.

Soons, M. B., Van Der Vlugt, C., Van Lith, B., Heil, G. W., \& Klaassen, M. (2008). Small seed size increases the potential for dispersal of wetland plants by ducks. Journal of Ecology, 96(4), 619-627.

Southwood, T. R. (1977). Habitat, the templet for ecological strategies?. Journal of animal ecology, 46(2), 337-365.

Stanley, E. H., Powers, S. M., \& Lottig, N. R. (2010). The evolving legacy of disturbance in stream ecology: concepts, contributions, and coming challenges. Journal of the North American Benthological Society, 29(1), 67-83.

Statzner, B., Hoppenhaus, K., Arens, M. \& Richoux, P. (1997) Reproductive traits, habitat use and templet theory: a synthesis of world-wide data on aquatic insects. Freshwater Biology, 38, 109-135.

Stoll, S., Sundermann, A., Lorenz, A. W., Kail, J., \& Haase, P. (2013). Small and impoverished regional species pools constrain colonisation of restored river reaches by fishes. Freshwater Biology, 58(4), 664-674.

Sundermann, A., Stoll, S., \& Haase, P. (2011). River restoration success depends on the species pool of the immediate surroundings. Ecological Applications, 21(6), 1962-1971.

Švamberková, E. \& Lepš, J. (2020). Experimental assessment of biotic and abiotic filters driving community composition. Ecology and evolution, 10(14), 7364-7376.

Svenning, J. C., \& Skov, F. (2007). Ice age legacies in the geographical distribution of tree species richness in Europe. Global Ecology and Biogeography, 16(2), 234-245.

Tachet, H., Richoux, P., Bournaud, M. \& Usseglio-Polatera, P. (2000) Invertébrés d'eau douce: systématique, biologie, écologie. CNRS Editions, Paris.

Tachet, H., Richoux, P., Bournaud, M., \& Usseglio-Polatera, P. (2010). Invertébrés d'eau douce: systématique, biologie, écologie (Vol. 15). Paris: CNRS éditions.

Taybi, A. F., Mabrouki, Y., Bozdoğan, H., \& Millán, A. (2021). Are aquatic Hemiptera good indicators of environmental river conditions?. Aquatic Ecology, 1-16.

Telford, R. J., Vandvik, V., \& Birks, H. J. B. (2006). Dispersal limitations matter for microbial morphospecies. Science, 312(5776), 1015-1015.

ter Braak, C. J. \& Looman, C. W. (1986). Weighted averaging, logistic regression and the Gaussian response model. Vegetatio, $65(1) ; 3-11$. 
ter Braak, C. J. \& van Dam, H. (1989). Inferring pH from diatoms: a comparison of old and new calibration methods. Hydrobiologia, 178(3): 209-223.

Terlizzi, A., Anderson, M. J., Bevilacqua, S., Fraschetti, S., Włodarska-Kowalczuk, M., \& Ellingsen, K. E. (2009). Beta diversity and taxonomic sufficiency: do higher-level taxa reflect heterogeneity in species composition?. Diversity and Distributions, 15(3), 450-458.

Thompson, R., \& Townsend, C. (2006). A truce with neutral theory: local deterministic factors, species traits and dispersal limitation together determine patterns of diversity in stream invertebrates. Journal of Animal Ecology, 75(2), 476-484.

Thuiller, W., Münkemüller, T., Lavergne, S., Mouillot, D., Mouquet, N., Schiffers, K., \& Gravel, D. (2013). A road map for integrating eco-evolutionary processes into biodiversity models. Ecology letters, 16, 94-105.

Tilman, D., May, R. M., Lehman, C. L., \& Nowak, M. A. (1994). Habitat destruction and the extinction debt. Nature, 371(6492), 65-66.

Toivonen, H., \& Nybom, C. (1989, January). Aquatic vegetation and its recent succession in the waterfowl wetland Koijärvi, S. Finland. In Annales Botanici Fennici (pp. 1-14). The Finnish Botanical Publishing Board.

Tomanova, S. \& Usseglio-Polatera, P. (2007) Patterns of benthic community traits in neotropical streams: relationship to mesoscale spatial variability. Fundamental and Applied Limnology, 170, 243-255.

Tonkin, J. D., Heino, J., Sundermann, A., Haase, P., \& Jähnig, S. C. (2016). Context dependency in biodiversity patterns of central German stream metacommunities. Freshwater Biology, 61(5), 607620.

Townsend, C. R., \& Hildrew, A. G. (1994). Species traits in relation to a habitat templet for river systems. Freshwater biology, 31(3), 265-275.

Townsend, C. R., Uhlmann, S. S., \& Matthaei, C. D. (2008). Individual and combined responses of stream ecosystems to multiple stressors. Journal of Applied Ecology, 45(6), 1810-1819.

Tylianakis, J. M., Laliberté, E., Nielsen, A., \& Bascompte, J. (2010). Conservation of species interaction networks. Biological conservation, 143(10), 2270-2279.

Ulrich, W., \& Gotelli, N. J. (2010). Null model analysis of species associations using abundance data. Ecology, 91(11), 3384-3397.

Ulrich, W., Piwczyński, M., Maestre, F. T., \& Gotelli, N. J. (2012). Null model tests for niche conservatism, phylogenetic assortment and habitat filtering. Methods in Ecology and Evolution, 3(5), 930-939.

Underwood, A. J. (1994). On beyond BACI: sampling designs that might reliably detect environmental disturbances. Ecological applications, 4(1), 3-15.

Uotila, P. (1971). Distribution and ecological features of hydrophytes in the polluted Lake Vanajavesi, $S$ Finland. In Annales Botanici Fennici (pp. 257-295). Societas Biologica Fennica Vanamo.

Vagvolgyi, J. (1975). Body size, aerial dispersal, and origin of the Pacific land snail fauna. Systematic Biology, 24(4), 465-488.

van Dam, H. (2013). Ontwikkeling module diatomeeën voor Volg- en Stuursysteem en KRW Verkenner. Rapport AWN 906, Stowa, 71 pp.

Van Dam, H., Mertens, A., \& Sinkeldam, J. (1994). A coded checklist and ecological indicator values of freshwater diatoms from the Netherlands. Netherland Journal of Aquatic Ecology, 28(1), 117-133.

Van Dam, H., Mertens, A., \& Sinkeldam, J. (1994). A coded checklist and ecological indicator values of freshwater diatoms from the Netherlands. Netherland Journal of Aquatic Ecology, 28(1), 117-133.

Van den Brink, P. J., Rubach, M. N., Culp, J. M., Pascoe, T., Maund, S. J., \& Baird, D. J. (2011). Traitsbased ecological risk assessment (TERA): Realizing the potential of ecoinformatics approaches in ecotoxicology. Integrated environmental assessment and management, 7(2), 169-171.

Van der Gucht, K., Cottenie, K., Muylaert, K., Vloemans, N., Cousin, S., Declerck, S., ... \& De Meester, L. (2007). The power of species sorting: local factors drive bacterial community composition over a wide range of spatial scales. Proceedings of the National Academy of Sciences, 104(51), 2040420409.

Van der Hoek, W. F., \& Verdonschot, P. F. M. (1994). Functionele karakterisering van aquatische ecotooptypen (No. 072). IBN.

Van der Lee, G. H. (2020a). Organisms make ecosystems function: Identifying functional indicators of anthropogenic stress in aquatic ecosystems. Thesis University of Amsterdam.

van der Lee, G. H., Kraak, M. H., Verdonschot, R. C., \& Verdonschot, P. F. (2020b). Persist or perish: critical life stages determine the sensitivity of invertebrates to disturbances. Aquatic Sciences, $82(2), 1-11$.

van Oorschot M., van Geest, G., de Niet, A. \& Riegman, R. (2012). Handleiding AQMAD 2.0 macrofyten. Stowa rapport 2012-09, 28 pp. 
Vandewalle, M., De Bello, F., Berg, M. P., Bolger, T., Doledec, S., Dubs, F., ... \& Woodcock, B. A. (2010). Functional traits as indicators of biodiversity response to land use changes across ecosystems and organisms. Biodiversity and Conservation, 19(10), 2921-2947.

Vanschoenwinkel, B., Gielen, S., Vandewaerde, H., Seaman, M., \& Brendonck, L. (2008). Relative importance of different dispersal vectors for small aquatic invertebrates in a rock pool metacommunity. Ecography, 31(5), 567-577.

Veech, J. A. (2013). A probabilistic model for analysing species co-occurrence. Global Ecology and Biogeography, 22(2), 252-260.

Veltman, C. J., Nee, S., \& Crawley, M. J. (1996). Correlates of introduction success in exotic New Zealand birds. The American Naturalist, 147(4), 542-557.

Verberk, W. C. E. P., Siepel, H. \& Esselink, H. (2008) Applying life-history strategies for freshwater macroinvertebrates to lentic waters. Freshwater Biology, 53, 1739-1753.

Verberk, W. C. E. P., Verdonschot, P. F. M., van Haaren, T., \& van Maanen, B. (2012). Milieu-en habitatpreferenties van Nederlandse zoetwatermacrofauna (No. 2012-19). Stowa.

Verberk, W. C., Van Noordwijk, C. G. E., \& Hildrew, A. G. (2013). Delivering on a promise: integrating species traits to transform descriptive community ecology into a predictive science. Freshwater Science, 32(2), 531-547.

Verberk, W. C., Van Noordwijk, C. G. E., \& Hildrew, A. G. (2013). Delivering on a promise: integrating species traits to transform descriptive community ecology into a predictive science. Freshwater Science, 32(2), 531-547.

Verdonschot Piet F.M. \& Ralf C.M. Verdonschot (2021). Tijdvertraging (time-lags) in regionale wateren. Kennisdocument Kennisimpuls waterkwaliteit, Zoetwaterecosystemen, Wageningen Environmental Research, Wageningen UR, Wageningen. $19 \mathrm{pp}$.

Verdonschot, P. F. M. \& Higler, L. W. G. (1992). Optima and tolerances of Trichoptera larvae for key factors in Dutch inland waters. In Proceedings of the seventh International Symposium on Trichoptera (pp. 293-296).

Verdonschot, P. F. M. (1990). Ecologische karakterisering van oppervlaktewateren in Overijssel: het netwerk van cenotypen als instrument voor ecologisch beheer, inrichting en beoordeling van oppervlaktewateren. Provincie Overijssel.

Verdonschot, P. F. M. (1990). Ecologische karakterisering van oppervlaktewateren in Overijssel: het netwerk van cenotypen als instrument voor ecologisch beheer, inrichting en beoordeling van oppervlaktewateren. Provincie Overijssel.

Verdonschot, P. F. M., Goedhart, P. W., Nijboer, R. C., \& Vlek, H. E. (2003b). Voorspelling van effecten van ingrepen in het waterbeheer op aquatische gemeenschappen: de ontwikkeling van cenotypenvoorspellingsmodellen voor beken en sloten in Nederland (No. 738). Alterra.

Verdonschot, P. F. M., Higler, L. W. G., Van der Hoek, W. F., \& Cuppen, J. G. M. (1992). A list of macroinvertebrates in Dutch water types: a first step towards an ecological classification of surface waters based on key factors. Hydrobiological Bulletin, 25(3), 241-259.

Verdonschot, P. F. M., Nijboer, R. C., Higler, L. W. G., \& van den Hoek, T. H. (2003a). Selectie van indicatoren voor oppervlaktewateren; invulling van indicatieve macrofauna, macrofyten en vissen voor Kaderrichtlijn Water typen (No. 865). Alterra.

Verdonschot, P. F., \& van der Lee, G. H. (2020). Perspectives on the functional assessment of multistressed stream ecosystems. Freshwater Science, 39(4), 605-620.

Verdonschot, P. F., \& Verdonschot, R. C. (2021). Ecologische systeembenadering en ecologische systeemanalyse (No. 2021-29). [Stichting Toegepast Onderzoek Waterbeheer (STOWA)].

Verdonschot, P.F.M. (2014). Ecologisch raamwerk voor aquatische ecosystemen. Amersfoort : STOWA, (Rapport / STOWA 2015-29) - p. 118

Vermonden, K., Leuven, R. S., van der Velde, G., Hendriks, A. J., van Katwijk, M. M., Roelofs, J. G., ... \& Sand-Jensen, K. (2010). Species pool versus site limitations of macrophytes in urban waters. Aquatic Sciences, 72(3), 379-389.

Vieira, N. K. M., Poff, N. L., Carlisle, D. M., Moulton, S. R., Koski, M. L. \& Kondratieff, B. C. (2006) A database of lotic invertebrate traits for North America. U.S. Geological Survey Data Series 187. http://pubs.usgs.gov/ds/ds187/.

Vieira, N. K., Poff, N. L., Carlisle, D. M., Moulton, S. R., Koski, M. L., \& Kondratieff, B. C. (2006). A database of lotic invertebrate traits for North America. US Geological Survey Data Series, 187, 1-15.

Vilmi, A., Karjalainen, S. M., Nokela, T., Tolonen, K., \& Heino, J. (2016). Unravelling the drivers of aquatic communities using disparate organismal groups and different taxonomic levels. Ecological Indicators, 60, 108-118. 
Muñoz-Colmenares, M. E., Soria, J. M., \& Vicente, E. (2021). Can zooplankton species be used as indicators of trophic status and ecological potential of reservoirs?. Aquatic Ecology, 1-14.

Lougheed, V. L., \& Chow-Fraser, P. (2002). Development and use of a zooplankton index of wetland quality in the Laurentian Great Lakes basin. Ecological Applications, 12(2), 474-486.

Sládeček, V. (1983). Rotifers as indicators of water quality. Hydrobiologia, 100(1), 169-201.

Kuczyńska-Kippen, N., Špoljar, M., Zhang, C., \& Pronin, M. (2020). Zooplankton functional traits as a tool to assess latitudinal variation in the northern-southern temperate European regions during spring and autumn seasons. Ecological Indicators, 117, 106629.

Violle, C., Nemergut, D. R., Pu, Z., \& Jiang, L. (2011). Phylogenetic limiting similarity and competitive exclusion. Ecology letters, 14(8), 782-787.Waite, I. R. (2014). Agricultural disturbance response models for invertebrate and algal metrics from streams at two spatial scales within the US. Hydrobiologia, 726(1), 285-303.

Walks, D. J., \& Cyr, H. (2004). Movement of plankton through lake-stream systems. Freshwater biology, 49(6), 745-759.

Warren, D. L., Glor, R. E., \& Turelli, M. (2008). Environmental niche equivalency versus conservatism: quantitative approaches to niche evolution. Evolution: International Journal of Organic Evolution, 62(11), 2868-2883.

Warwick, R. M. (1993). Environmental impact studies on marine communities: pragmatical considerations. Australian Journal of Ecology, 18(1), 63-80.

Webb, C. O., Ackerly, D. D., McPeek, M. A., \& Donoghue, M. J. (2002). Phylogenies and community ecology. Annual review of ecology and systematics, 33(1), 475-505.

Weiher, E., Freund, D., Bunton, T., Stefanski, A., Lee, T., \& Bentivenga, S. (2011). Advances, challenges and a developing synthesis of ecological community assembly theory. Philosophical Transactions of the Royal Society B: Biological Sciences, 366(1576), 2403-2413.

Weisner, S. E. (1987). The relation between wave exposure and distribution of emergent vegetation in a eutrophic lake. Freshwater Biology, 18(3), 537-544.

Weisner, S. E. (1991). Within-lake patterns in depth penetration of emergent vegetation. Freshwater Biology, 26(1), 133-142.

Weisner, S. E. (1991). Within-lake patterns in depth penetration of emergent vegetation. Freshwater Biology, 26(1), 133-142., R. L., \& Halls, A. (2004). Dependence of tropical river fisheries on flow. In Proceedings of the second international symposium on the management of large rivers for fisheries (Vol. 2, pp. 267-283). RAP Publication 2004/16. Food and Agriculture Organization of the United Nations (FAO).

Welcomme R.L. \& Halls A. 2001. Some considerations of the effects of differences in flood patterns on fish populations. Ecohydrology and Hydrobiology, 1: 313-321.

Welcomme, R. L. (1979). Fishery management in large rivers. Food and Agriculture Organisation: Rome. ISBN 92-5-100764-0. 60 pp.

Welcomme, R. L., Winemiller, K. O., \& Cowx, I. G. (2006). Fish environmental guilds as a tool for assessment of ecological condition of rivers. River Research and Applications, 22(3), 377-396.

Whittier, T. R., \& Kincaid, T. M. (1999). Introduced fish in northeastern USA lakes: regional extent, dominance, and effect on native species richness. Transactions of the American Fisheries Society, $128(5), 769-783$.

Wiens, J. J., \& Graham, C. H. (2005). Niche conservatism: integrating evolution, ecology, and conservation biology. Annu. Rev. Ecol. Evol. Syst., 36, 519-539.

Wiens, J. J., Ackerly, D. D., Allen, A. P., Anacker, B. L., Buckley, L. B., Cornell, H. V., ... \& Stephens, P. R. (2010). Niche conservatism as an emerging principle in ecology and conservation biology. Ecology letters, 13(10), 1310-1324.

Willén, E. (2000). Phytoplankton in water quality assessment-an indicator concept. Hydrological and limnological aspects of lake monitoring, 2, 58-80.

Willén, E. (2000). Phytoplankton in water quality assessment-an indicator concept. Hydrological and limnological aspects of lake monitoring, 57, 80.

Wisz, M. S., Pottier, J., Kissling, W. D., Pellissier, L., Lenoir, J., Damgaard, C. F., ... \& Svenning, J. C. (2013). The role of biotic interactions in shaping distributions and realised assemblages of species: implications for species distribution modelling. Biological reviews, 88(1), 15-30.

Woelkerling, W. J., \& Gough, S. B. (1976). Wisconsin Desmids. III. Desmid community composition and distribution in relation to lake type and water chemistry. Hydrobiologia, 51(1), 3-31.

Woodward, G. U. Y., \& Hildrew, A. G. (2002). Body-size determinants of niche overlap and intraguild predation within a complex food web. Journal of Animal Ecology, 71(6), 1063-1074.Woodward, 
G., Ebenman, B., Emmerson, M., Montoya, J. M., Olesen, J. M., Valido, A., \& Warren, P. H. (2005). Body size in ecological networks. Trends in ecology \& evolution, 20(7), 402-409.

Yoder, C. O. \& Rankin, E. T. (1995). Biological response signatures and the area of degradation value: New tools for interpreting multimetric data. In Davis WS, Simon TP, eds, Biological Assessment and Criteria: Tools for Water Resource Planning and Decision Making. CRC, Boca Raton, FL, USA, pp 263-286.

Yoder, C. O., \& Rankin, E. T. (1998). The role of biological indicators in a state water quality management process. Environmental monitoring and assessment, 51(1), 61-88.

Zobel, M., Otto, R., Laanisto, L., Naranjo-Cigala, A., Pärtel, M., \& Fernández-Palacios, J. M. (2011). The formation of species pools: historical habitat abundance affects current local diversity. Global Ecology and Biogeography, 20(2), 251-259.

García-Chicote, J., Armengol, X., \& Rojo, C. (2018). Zooplankton abundance: a neglected key element in the evaluation of reservoir water quality. Limnologica, 69, 46-54. 